\title{
Working
}

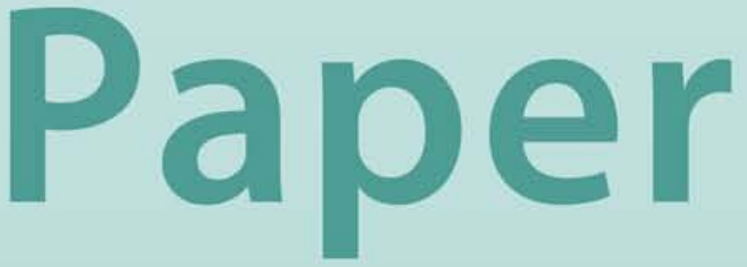




\title{
France in the Global Economy: A Structural Approximate Dynamic Factor Model Analysis
}

\author{
Alain Kabundi and \\ Francisco Nadal De Simone
}




\title{
IMF Working Paper
}

European Department

\section{France in the Global Economy: A Structural Approximate Dynamic Factor Model Analysis Prepared by Alain Kabundi ${ }^{1}$ and Francisco Nadal De Simone', *}

Authorized for distribution by Luc Everaert

June 2007

\begin{abstract}
This Working Paper should not be reported as representing the views of the IMF.

The views expressed in this Working Paper are those of the author(s) and do not necessarily represent those of the IMF or IMF policy. Working Papers describe research in progress by the author(s) and are published to elicit comments and to further debate.
\end{abstract}

This study identifies the main shocks that cause fluctuations in French output and their channels of transmission. It uses a large-dimensional structural approximate dynamic factor model. There are three main findings. First, common shocks, especially demand shocks, which seem to originate from the U.S., play an important role in explaining French economic activity. While international trade, relative prices, and FDI flows are the main channels of transmission, the stock market, consumer confidence, and interest rates also matter. Second, France's integration with the rest of the world has increased over time. Third, there is some tentative evidence of regional components in explaining French output fluctuations; countryspecific components also contribute. The predominance of exogenous factors affecting French output, the asymmetry in the transmission of shocks, and France's participation in a currency area, argue for making French goods, services, and labor markets as flexible as possible.

JEL Classification Numbers:C3, E32, F00, E5

Keywords: Dynamic factor models, international business cycles, sign restrictions.

Authors’ E-Mail Addresses: akabundi@uj.ac.za, fnadaldesimone@imf.org

\footnotetext{
${ }^{1}$ Department of Economics, University of Johannesburg.

${ }^{2}$ European Department, IMF.

* The authors thank Céline Allard, Luc Everaert, Alessandro Leipold, Rodolfo Luzio, Werner Schule, and Edda Zoli for their comments on an earlier version of the paper, and Sandra Eickmeier for her assistance with the main Matlab codes used. The authors are also indebted to participants at the Bundesbank seminar, at the French Minister of Finance seminar and, especially, to a French discussant of the paper, for their valuable insights. Susan Becker did an efficient data management. Errors and omissions are the authors' sole responsibility. The views expressed in this study are those of the authors and not of the International Monetary Fund or the University of Johannesburg, with which the authors are affiliated.
} 


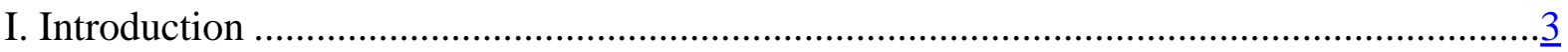

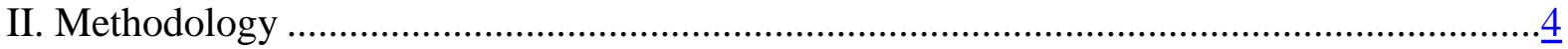

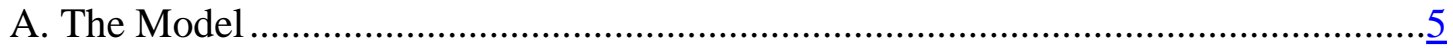

B. Economic Conditions for Shocks Identification ................................................ $\underline{6}$

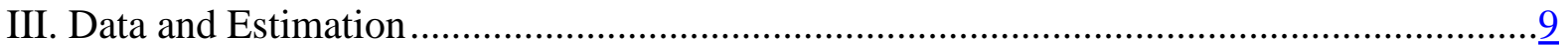

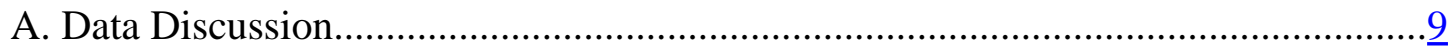

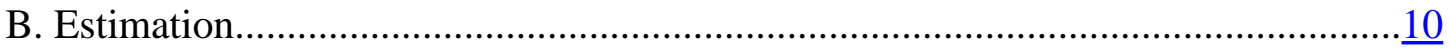

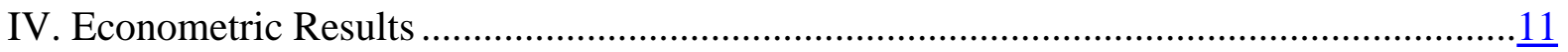

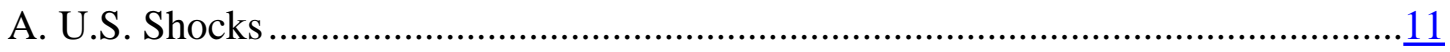

B. Channels of Transmission of U.S. Shocks to France ....................................... $\frac{12}{12}$

C. Is There Evidence of Increasing Interdependence Among Countries? ....................15

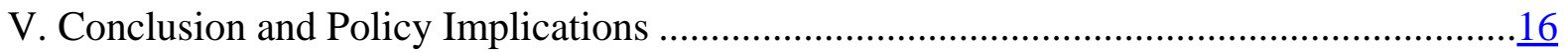

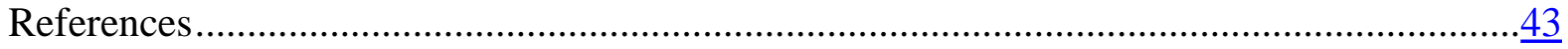

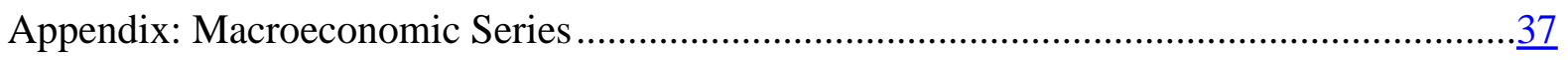

Figures

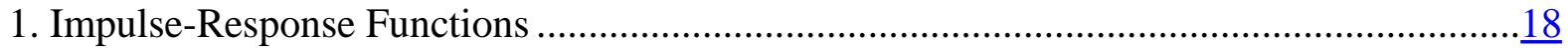

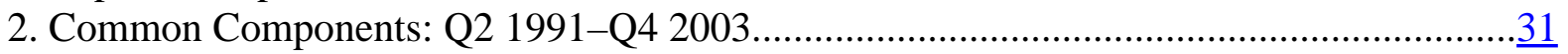

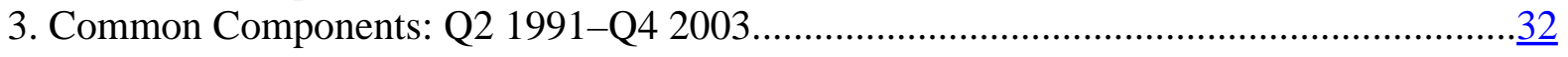

Tables

1a. Forecast Error Variance of the Common Components of USA Variables Explained by the USA Supply Shock and the Demand Shock, 1980-2003 ......................33

1b. Forecast Error Variance of the Common Components of France Variables Explained by the USA Supply Shock and the Demand Shock, 1980-2003 ......................33

2. Forecast Error Variance of the Common Components of German Variables Explained by the USA Supply Shock and the Demand Shock, 1980-2003 .....................34

3a. Forecast Error Variance of the Common Components of French Variables Explained by the USA Supply Shock and the Demand Shock, 1991-2003 ...................... 35

3b. Forecast Error Variance of the Common Components of German Variables Explained by the USA Supply Shock and the Demand Shock, 1991-2003.

4a. Forecast Error Variance of the Common Components of French Variables Explained by the G7 Excluding France Supply Shock and the Demand Shock, 1991-2003.

4b. Forecast Error Variance of the Common Components of French Variables Explained by the Euro Area Excluding France Supply Shock and the Demand Shock, 1991-2003. 


\section{INTRODUCTION}

Global developments affect the French economy significantly. Standard sources of fluctuations in economic activity include economic developments in trading partners, monetary and exchange rate developments, oil price changes, domestic fiscal policy, ongoing structural reforms, and productivity shocks. Observers of the French economy note that a significant part of fluctuations in French economic activity can be attributed to external sources, though the channels of transmission sometimes defy standard models. For example, French and German consumer confidence indices and French and U.S. business confidence indices exhibit a significant comovement; similarly, there is a strong comovement between the national index of stock prices and the performance of the U.S. economy. Moreover, the role of foreign direct investment (FDI) flows seems sometimes downplayed in empirical work as a relevant additional avenue linking French activity with U.S. activity.

New statistical techniques allow a more reliable extrication of global factors and the identification of the channels via which they interact with the French economy. With recent advances in statistical technology, it has become possible to better assess the sources of comovement of economic activity across countries and the channels of transmission of country- or region-specific shocks. The main reason is that the new models allow the conditions to recover structural shocks to be satisfied more easily, in contrast to the often used small-size structural VARs, where such conditions were unlikely to be met (Hansen and Sargent, 1991; and Fernández-Villaverde and others, 2005). Large dynamic factor models permit the exploitation of the wealth of information included in large panels (Forni, Hallin, Lippi, and Reichlin, 2000; and Kose, Otrok, and Whiteman, 2003; Kapetanios and Marcellino, 2006) and a look inside the "black box" of factor models (Forni, Giannone, Lippi, and Reichlin, 2005; and Eickmeier, 2006). Accordingly, these factors can be related to economically meaningful shocks, and the type of large information sets that economic agents have access to can be taken fully into account. In this vein, two main novel approaches have recently been used: Eickmeier (2005) analyzed the transmission of business cycles from the United States to Germany; and Forni, Giannone, Lippi, and Reichlin (2005) revisited the VAR results of King, Plosser, Stock, and Watson (1991) to identify U.S. shocks on output, consumption and investment.

This paper continues empirical work using factor models and expands it so as to identify the structural shocks that drive French business cycles. Building on previous work using factor models to explain French economic activity and prices (e.g., Nadal De Simone, 2002 and 2005; and Kabundi, 2004), this paper follows Eickmeier's (2005) framework and uses a signrestriction strategy to identify the main shocks that affect the French economy and the channels through which it interacts with the global economy. This paper fits in three strands of the literature: first, it relates to the study of the cyclical comovement of activity among countries (e.g., IMF, 2001; and Montfort, Rennee, Rüffer, and Vitale, 2004); second, it is part of studies that explore the channels of transmission of economic shocks across countries (e.g., Kose, Prasad, and Terrones, 2003; and Imbs, 2004); and third, it contributes to the structural VAR literature (Lumsdaine and Prasad, 2003; and Eickmeier and Breitung, 2005) as the structural shocks are identified using that approach. 
This study contains three main findings. First, U.S. shocks, especially demand shocks, seem to play an important role in explaining French economic activity, as reflected in the share of the forecast error variance of French variables they account for. Trade in goods and services, relative prices, and FDI flows are the main channels of transmission for all shocks. The stock market and consumer confidence channels seem relatively more relevant for the transmission of U.S. supply shocks, while interest rates seem instead relatively more important for the transmission of demand shocks. Second, indicating France's increasing regional and global economic integration, the share of French GDP fluctuations explained by the common components has risen over time-a phenomenon also found in Germany. U.S. and G7 (excluding France) economic activity affect French output relatively more via demand shocks while euro area (excluding France) activity affects French output relatively more via supply shocks. Finally, there is some tentative evidence of a possibly small role for regional components, independent of the global common components, in explaining fluctuations in French economic activity. Idiosyncratic components also contribute to the explanation of French output fluctuations. Given the importance of exogenous factors for French economic activity and the fact that France is part of a currency area, French goods, services, and labor markets should be made as flexible as possible. This will reduce income volatility and increase welfare.

The remainder of the paper is organized as follows: Section II discusses the model and the economic conditions for the identification of structural shocks. Section III explains the data, data transformation procedures, and the estimation technique. Section IV discusses the econometric results on the source of the shocks and the channels of transmission. The last section concludes and discusses the policy implications of the paper.

\section{Methodology}

The methodology used in this paper comprises two main steps. First, estimating the common components of a large panel of data, and second, identifying a reduced number of structural shocks that explain the common components of the variables of interest. In a streamlined way, the estimation procedure requires the following:

- Use of a large panel of data fulfilling the condition that the number of time series is "much larger" than the number of observations (in a sense to be made clear below).

- Decompose each time series into two unobserved parts: its common component, driven by shocks common to all series, and its idiosyncratic component.

- Write the series' common components as a VAR of low order (often of order one) to represent the reduced form of the model.

- Estimate the VAR to obtain the coefficients matrix and the reduced-form residuals.

- Orthogonalize those residuals and obtain the impulse-response functions and forecast error variances.

- Assume that the orthogonalized residuals are linearly correlated to a vector of "fundamentals" driving the variable of interest via a matrix such that the first shock explains as much as possible of the forecast error variance of the common components; the second one explains as much as possible of the remaining variance, and so on.

- Concentrate on the first few principal component shocks (neglect others), e.g., the first two principal component shocks. 
- Compute the impulse-response functions and the variance decomposition of the few principal component shocks.

- Recover the structural shocks that explain the principal component shocks by rotating a matrix such that orthogonal structural shocks produce impulse-responses satisfying a set of economically meaningful (sign) restrictions.

- Construct confidence intervals for the impulse-responses using bootstrapping so as to account for biases in the VAR coefficients and the agnostic nature of the model.

The estimation procedure is explained in detail below. The reader not interested in technical details can skip the remainder of this section.

\section{A. The Model}

This paper uses a large dimensional approximate dynamic factor model. As in Eickmeier (2005), this paper uses the static factor model of Stock and Watson (1998 and 2002). This model is closely related to the traditional factor models of Sargent and Sims (1977) and Geweke (1977), except that it admits the possibility of serial correlation and weakly crosssectional correlation of idiosyncratic components, as in Chamberlain (1983) and Chamberlain and Rothschild (1983). Similar models have recently been used by Giannone, Reichlin, and Sala (2002); Forni and others (2005); and Eickmeier (2005).

The intuition behind the approximate dynamic factor model analysis is simple. A vector of time series $Y_{t}=\left(y_{1 t}, y_{2 t}, \ldots, y_{N t}\right)^{\prime}$ can be represented as the sum of two latent components, a common component $X_{t}=\left(x_{1 t}, x_{2 t}, \ldots, X_{N t}\right)^{\prime}$ and an idiosyncratic component $\Xi_{t}=\left(\varepsilon_{1 t}, \varepsilon_{2 t}, \ldots, \varepsilon_{N t}\right)^{\prime}$

$Y_{t}=X_{t}+\Xi_{t}$

$Y_{t}=C F_{t}+\Xi_{t}$

where $F_{t}=\left(f_{1 t}, f_{2 t}, \ldots, f_{r t}\right)^{\prime}$ is a vector of $r$ common factors, and $C=\left(c_{1}^{\prime}, c_{2}^{\prime}, \ldots, c_{N}^{\prime}\right)^{\prime}$ is a $N \times r$ matrix of factor loadings, with $r<<N$. The common component $X_{t}$, which is a linear combination of common factors, is driven by few common shocks, which are the same for all variables. Nevertheless, the effects of common shocks differ from one variable to another due to different factor loadings. In this framework and in contrast to standard common component analysis, the idiosyncratic component is driven by idiosyncratic shocks, which are specific to each variable. The static factor model used here differs from the dynamic factor model in that it treats lagged or dynamic factors $F_{t}$ as additional static factors. Thus, common factors include both lagged and contemporaneous factors.

The identification of the common components requires that the number of series be much larger than the number of observations. Stock and Watson demonstrate that by using the law of large number (as $T, N \rightarrow \infty$ ), the idiosyncratic component, which is weakly correlated by construction, vanishes; and therefore, the common component can be easily estimated in 
a consistent manner by using standard principal component analysis. The first $r$ eigenvalues and eigenvectors are calculated from the variance-covariance matrix $\operatorname{cov}\left(Y_{t}\right)$.

$X_{t}=V V^{\prime} Y_{t}$

and since the factor loadings $C=V$, equation (1) becomes,

$F_{t}=V^{\prime} Y_{t}$

From (1), the idiosyncratic component is

$\Xi_{t}=Y_{t}-X_{t}$

From all the more or less formal criteria to determine the number of static factors $r$, Bai and $\mathrm{Ng}$ (2002) information criteria was followed. As in Forni and others (2005), $F_{t}$ was approximated by an autoregressive representation of order $1^{3}$ :

$F_{t}=B F_{t-1}+u_{t}$,

where $B$ is a $r \times r$ matrix and $u_{t}$ a $r \times t$ vector of residuals. Equation (5) is the reduced form model of (1).

\section{B. Economic Conditions for Shocks Identification}

Once a decision is taken on the process followed by the common components, structural shocks have to be identified. The identification of structural shocks is achieved by focusing on the reduced form VAR residuals of (5). Following Eickmeier (2005), the identification scheme has three steps.

First, maximize the variance of the forecast error of the chosen variable and calculate impulse-response functions. As in Uhlig (2003), rather than identifying a shock as, say, a productivity shock, and calculate its contribution to the variance of the $k$-step ahead prediction error of, say, U.S. GDP, a few major shocks driving GDP are identified. ${ }^{4}$ This implies maximizing the explanation of the chosen variance of the $k$-step ahead forecast error of GDP with a reduced number of shocks. ${ }^{5}$ To this end, $k$-ahead prediction errors $u_{t}$ are

\footnotetext{
${ }^{3}$ VAR(1) provides a dynamic representation which is parsimonious and quite general (for more details, see Gianonne, 2005). The residuals $u_{t}$ were white noise and thus an autoregressive process of order 1 was chosen.

${ }^{4}$ Uhlig (2003) shows that two shocks are sufficient to explain 90 percent of the variance at all horizons of real U.S. GNP.

${ }^{5}$ If, for example, two orthogonal shocks are identified, it is incorrect to identify the first shock as the one corresponding to the first eigenvalue and the second orthogonal shock as the one corresponding to the second eigenvalue (see Uhlig, 2003). The two orthogonal shocks identified generate together the total variation which explanation is being maximized. However, there are multiple possible combinations of those orthogonal shocks all of which will still explain the total variation chosen: as an illustration, and measuring angles in degrees, the
} 
decomposed into $k$ mutually orthogonal innovations using the Cholesky decomposition. The lower triangular Cholesky matrix $A$ is such that $u_{t}=A v_{t}$ and $E\left(v_{t} v_{t}^{\prime}\right)=I$. Hence,

$\operatorname{cov}\left(u_{t}\right)=A E\left(v_{t} v_{t}^{\prime}\right) A^{\prime}=A A^{\prime}$

The impulse-response function of $y_{i t}$ to the identified shock in period $k$ is obtained as follows:

$R_{i k}=C_{i} B^{k} A$,

with $c_{\mathrm{i}}$ the ith row of factor loadings of $C$ and with a corresponding variance-covariance matrix $\sum_{j=0}^{k} R_{i j} R_{i j}^{\prime}$.

Second, the identified shocks are assumed to be linearly correlated to a vector of fundamentals. The fundamental forces $\omega_{t}=\left(\omega_{1 t}, \omega_{2 t}, \ldots, \omega_{r t}\right)^{\prime}$ behind U.S. GDP are correlated to the identified shocks through the $r \times r$ matrix $Q$. Thus,

$v_{t}=Q \omega_{t}$.

The intuition of the procedure is to select $Q$ in such a way that the first shock explains as much as possible of the forecast error variance of the U.S. GDP common component over a certain horizon $k$, and the second shock explains as much as possible of the remaining forecast error variance. Focusing on the first shock, the task is to explain as much as possible of its error variance

$$
\sigma^{2}(k)=\sum_{j=0}^{k}\left(R_{i j} q_{1}\right)\left(R_{i j} q_{1}\right)^{\prime},
$$

where $i$ is, in our example, the U.S. GDP, and $q_{1}$ is the first column of $Q$. The column $q_{1}$ is selected in such a way that $q_{1}^{\prime} \sigma^{2} q_{1}$ is maximized, that is

$$
\begin{aligned}
& \begin{aligned}
\sigma^{2}(k) & =\sum_{j=0}^{k}\left(R_{i j} q_{1}\right)\left(R_{i j} q_{1}\right)^{\prime} \\
& =q_{1}^{\prime} S_{i k} q_{1}
\end{aligned} \\
& \text { where } S_{i k}=\sum_{j=0}^{k}(k+1-j) R_{i j}^{\prime} R_{i j} .
\end{aligned}
$$

pairings of orthogonal shocks with rotation angles $\{0,90\}$ or $\{10,100\}$ or $\{80,170\}$ would be equally acceptable. The grid of the angle of rotation can be different, of course. So the number of possibilities is vast. This paper uses a grid of 30 degrees. 
The maximization problem subject to the side constraint $q_{1}^{\prime} q_{1}=1$, can be written as the Lagrangean,

$L=q_{1}^{\prime} S_{i k} q_{1}-\lambda\left(q_{1}^{\prime} q_{1}-1\right)$,

where $\lambda$ is the Lagrangean multiplier. From (10), $q_{1}$ is the first eigenvector of $S_{i k}$ with eigenvalue $\lambda$ and, therefore, the shock associated with $q_{1}$ is the first principal component shock. $Q$ is the matrix of eigenvectors of $S,\left(q_{1}, q_{2}, \ldots, q_{r}\right)$, where $q_{l}(l=1, \ldots, r)$ is the eigenvector corresponding to the $l^{\text {th }}$ principal component shock. Along the lines of Uhlig (2003), Eickmeier (2005), and Altig and others (2002), it is posed: $k=0$ to $k=19$, i.e., five years, which covers short- as well as medium-run dynamics.

Finally, orthogonal shocks are identified by rotation. If two shocks are identified, following Canova and de Nicoló (2003), the orthogonal shocks vector $\omega_{t}=\left(\omega_{1 t}, \omega_{2 t}\right)^{\prime}$ is multiplied by a $2 \times 2$ orthogonal rotation matrix $P$ of the form:

$P=\left(\begin{array}{lr}\cos (\theta) & -\sin (\theta) \\ \sin (\theta) & \cos (\theta)\end{array}\right)$,

where $\theta$ is the rotation angle; $\theta \in(0, \pi)$, produces all possible rotations and varies on a grid. If $\theta$ is fixed, and $q=5$, there are $q(q-1) / 2$ bivariate rotations of different elements of the VAR. Following the insights of Sims (1998), and as in Peersman (2005); Canova and de Nicoló (2003); and Eickmeier (2005); the number of angles between 0 and $\pi$ is assumed to be 12: this implies $6,191,736,421 \times 10^{10}\left(12^{10}\right)$ rotations. Hence, the rotated factor $w_{t}=P w_{t}$ explains in total all the variation measured by the first two eigenvalues. This way, the two principal components $\omega_{i}$ are associated to the two structural shocks $w_{i}$ through the matrix $P$, and the impulse-response functions of the two structural shocks on all the fundamental forces can be estimated.

A sign-identification strategy is followed to identify the shocks. The method was developed by Peersman (2005). This strategy imposes inequality sign restrictions on the impulse response functions of variables based on a typical aggregate demand and aggregate supply framework. ${ }^{6}$ Only those rotations among all possible $q \times q$ rotations that have a structural meaning are chosen. The text table displays the sign restrictions for the identification of shocks that are imposed contemporaneously and during the first year after the shock. ${ }^{7}$

\footnotetext{
${ }^{6}$ See Peersman (2005), for more technical details.

${ }^{7}$ Notice that inequalities include zero responses, some of which are usually excluded in the VAR literature. As shown by Peersman (2005), this may sometimes be unduly restrictive. Peersman shows, for example, that oil prices do react within one quarter to demand and monetary policy shocks. In contrast, imposing the standard contemporaneous zero restriction on oil prices make them appear as exogenous rather than as endogenous responses of an asset price to demand disturbances and monetary policy shocks.
} 
Identification Inequalities

\begin{tabular}{lccc}
\hline & Positive Supply Shock & Positive Demand Shock & Monetary Policy Tightening \\
\hline GDP & $\geq 0$ & $\geq 0$ & $\leq 0$ \\
Prices & $\leq 0$ & $\geq 0$ & $\leq 0$ \\
Interest rates & $\leq 0$ & $\geq 0$ & $\geq 0$ \\
\hline
\end{tabular}

As in major standard macroeconomic models, a positive supply shock has a nonnegative effect on output and a nonpositive effect on prices during the first four quarters following the shock. ${ }^{8}$ A positive demand shock has a nonnegative effect on both output and prices during the first four quarters following the shock. A monetary policy tightening has a nonpositive effect on both output and prices during the first four quarters following the shock.

\section{DAta AND Estimation}

\section{A. Data Discussion}

This paper uses a large data panel. The data panel comprises 482 quarterly series $(N=482)$ covering the period 1980:Q1-2003:Q4. This implies 96 observations $(T=96)$. The countries included in the sample are France, Germany, Italy, Japan, Spain, the United Kingdom, and the United States. In addition to national variables, a set of global variables are included, such as a crude oil prices and a commodity industrial inputs price index. The variables cover the real sector of the economy including consumption, investment, international trade in goods and services, portfolio flows and FDI flows, prices, financial variables, and confidence indicators.

For comparison purposes, a shorter time period is also estimated. A data panel for a shorter time period but including the same macroeconomic time series plus a G7 (excluding France) and a euro area (excluding France) real GDP series, and two corresponding price series, is also used $(N=486)$. This data set covers the period 1991:Q1-2003:Q4, or 51 observations $(T=51)$. The complete list of variables used in this study is in Appendix I.

Variables were transformed, if necessary, to make them covariance stationary. All the variables are seasonally adjusted. The unit root test developed by Elliot, Rothenberg, and Stock (1996); was applied to all series to decide on the statistical transformation necessary to make them stationary, if needed. The unit root tests included a constant and a deterministic trend. The number of lags was chosen using the Schwarz information criterion and taking care that no serial correlation was left in the residuals. In a few cases, unit root test results were unclear. In those cases, a unit root test with the null hypothesis of stationarity proposed by Kwiatowski, Phillips, Schmidt, and Shin (1992); was used. The statistical treatment of the

\footnotetext{
${ }^{8}$ Clearly, a set of restrictions based on neoclassical model features would produce different results.
} 
series is summarized in Appendix I. All series were standardized to have zero mean and unit variance.

\section{B. Estimation}

The first step of the estimation is the determination of the number of factors. The estimation was done assuming that the series follow an approximate dynamic factor model. ${ }^{9}$ As discussed in Section II, the first step is to decide on the number of static factors $r$ making up the common component. Using Bai's and Ng's (2002) selection criteria, five factors were retained. Not much can be concluded from the inspection of the factors and their loadings, however, because factors are identified only up to a rotation. Moreover, factors can be a linear combination not only of their contemporaneous values, but also of their lags.

Next, the identification of the structural shocks followed the approach of the structural VAR literature. No identification technology is completely foolproof, however. While the identification technology followed in this paper is flexible enough not to require special restrictions to disentangle common shocks from the contemporaneous transmission of regional or country-specific shocks, it does require additional work, for example, to confirm the source of shocks (e.g., that the shocks originate in the U.S. economy). In order to properly distinguish a global (common) shock from the transmission within the same period of a country- or regional-specific shock, following Eickmeier (2005), this paper does not restrict the impact effect of the shock. Moreover, after identifying two U.S. shocks and giving them an economic interpretation, this study performs the same analysis on a data set containing only U.S. variables. It finds that the impulse-responses of the U.S.-only data set and the broader data set are similar, bringing thus further comfort as to the identification of the source of the shocks. In addition, to test the relative importance of U.S. shocks as sources of disturbances that impact on French activity, the same identification restrictions are imposed on a G7 aggregate of economic activity (excluding France). Finally, the same approach is applied to a euro area aggregate of economic activity (excluding France) to probe the data for what could be a source of "regional” shocks.

Only two structural shocks could be identified. As explained in Section B, the identification procedure proposed by Uhlig (2003) was applied to the common components of U.S. GDP to find a reduced number of structural shocks that maximizes the explanation of its forecast error variance over 20 periods. The procedure was designed to identify three shocks, but could extract two shocks, which suffice to explain 98 percent of the forecast error variance of the common component of U.S. real GDP.

Sign restrictions on impulse response functions were used to provide economic meaning to the structural shocks. Following Peersman (2005), the angle rotations were applied to the first two principal component shocks taking as pairs a supply shock together with a monetary policy shock, a demand shock together with a monetary policy shock, and a supply and a demand shock together. The bootstrap was made up of 500 draws. In the case of the

\footnotetext{
${ }^{9}$ We are deeply grateful to Sandra Eickmeier for having provided us with the main code for the estimation and for her technical support and insights.
} 
U.S. shocks, only the pair of demand and supply shocks could be identified; no pair containing a monetary policy shock could be identified. ${ }^{10}$ The same results obtained when identifying G7 and euro area shocks. ${ }^{11}$ The impulse-response functions are calculated for the first five years to display the cyclical pattern associated with the structural shocks. Both the median response and a 90 percent bootstrapped confidence band are estimated.

\section{ECONOMETRIC RESULTS}

\section{A. U.S. Shocks}

In the tradition of the structural VAR literature, results are presented in the form of variance decomposition and impulse-response functions. Table 1 shows the variance shares of the common components of the data set, and the forecast error variance of the common components (henceforth, error variance) of U.S. and French variables explained by the two identified U.S. shocks. ${ }^{12}$ For comparison purposes, Table 2 displays the error variance of German variables explained by the U.S. shocks. Figure 1 shows the impulse-response functions of the U.S. shocks and their impact on U.S. and French variables.

The supply and demand shocks account for 98 percent of the error variance of U.S. GDP common components. When the full sample period, i.e., $N=482$ series and $T=95$ observations is used, the supply and demand shocks from the United States account for 87 percent and 11 percent of the error variance of U.S. GDP over 20 quarters, respectively. The variance share of U.S. GDP common components is 54 percent. $^{13}$

The U.S. supply shocks are relatively more important than demand shocks. The relatively larger importance of supply shocks is consistent with the literature on real business cycles that stresses these shocks (i.e., productivity-driven shocks) as the most significant source of U.S. business cycles. Consistently, supply shocks are far more persistent than demand shocks. The results are broadly in agreement with those of Eickmeier (2005). ${ }^{14}$ Positive

\footnotetext{
${ }^{10}$ Before one can draw the conclusion that monetary policy contributes little to business cycle fluctuations, it would be advisable to work with a more elaborate sign restriction for monetary policy. This is clearly beyond the scope of this paper.

11 The identification of the U.S. shocks required 524 draws, while 639 and 502 draws were necessary for the identification of the G7 and the euro area economic activity shocks, respectively.

12 Technically, the variance shares of the common components are independent of the shocks identified.

${ }^{13}$ From a purely technical viewpoint, it is not correct to weigh the forecast error variance of a given variable by the variance share of its common components; the variance share of the common components is calculated for the first difference of the variable, whereas the forecast error variance refers to the levels of the variable (and specific forecast horizons). Similarly, the stochastic nature of the results should be kept in mind when relating the variance share of the common components to accounting identities based on data that comprises both the common and the idiosyncratic components.

14 The impulse-response functions of short- and long-term interest rates are particularly sensitive to the procedure applied to make the series stationary; this is a problem likely related to the difficulty encountered by unit root tests in providing conclusive evidence on the order of integration of those same variables. Results
} 
demand shocks result in increased investment and consumption, with the rise in the latter relatively less persistent (Figure 1). Following a mild initial increase, productivity declines after a few quarters as the strong effect of the shock on employment is relatively protracted. Given that the measure of capacity utilization used includes new hiring, and that investment, consumption and government net savings increase, demand shocks may be capturing investment-driven cycles (less likely, consumption-driven ones). In the same vein, interest rates rise, especially short-term interest rates, as monetary policy may be trying to offset the effects of the economic expansion on prices as reflected in the CPI. Consistently, the money stock (M1) falls. Finally, and in contrast to supply shocks, demand shocks have virtually no effects on stock prices after 6-8 quarters.

Indirect and direct evidence supports the U.S. origin of the shocks. First, it is noteworthy that the identification strategy followed in this study, by construction, extracts supply and demand shocks that maximize the explained forecast error variance of the common components of U.S. real GDP. Second, indirect and direct evidence suggesting that the source of the identified shocks is the United States is the following. Indirect evidence comes from a dataset containing only U.S. variables. The resulting impulse-response functions were similar to those of the full sample (not shown). Further indirect evidence results from the relatively low values of the common components share of some global variables (i.e., crude oil prices, 26 percent, commodity metal prices, 19 percent, and a commodity industrial input index, 33 percent); it seems unlikely that the identified shocks are global (common) as opposed to U.S.-specific. ${ }^{15}$ Finally, indirect support for the result that the shocks originate in the United States can be gathered, as discussed below, from the observation that most effects of the U.S. shocks on French variables error variance are significantly smaller than on U.S. variables; given the relatively lower size and larger openness of the French economy, those features of the results are more consistent with a U.S. source than with a global source of the shocks. The direct evidence on the U.S. source of the shocks comes from the estimation of the cross-spectrum of the common components of U.S. and France's GDP (Figure 2, left side panels). The phase angle is clearly positive in periodicities between 2 and 8 years, the business cycle band, indicating that U.S. GDP common components lead French GDP common components at that frequency band. ${ }^{16}$

\section{B. Channels of Transmission of U.S. Shocks to France}

Broadly speaking, U.S. supply shocks are transmitted to France less forcefully than U.S. demand shocks, and transmission channels go beyond the traditional trade channel. U.S. demand shocks explain over $1 / 3$ of the error variance of French GDP common components while U.S. supply shocks explain less than $1 / 4$. The variance shares of French variables suggest that foreign trade and relative prices-i.e., especially terms of trade, and much less so the real exchange rate-matter for the transmission of both U.S. shocks.

displayed in the paper use differenced interest rate series. The short-term interest rate behavior is difficult to explain as it falls only marginally following the shock and during a very short period of time.

${ }^{15}$ Crude oil prices are a simple average of dated Brent, West Texas Intermediate and Dubai Fateh oil prices.

${ }^{16}$ Anticipating results, French GDP is led exclusively by U.S. GDP in periodicities between two and four years. 
However, while U.S. supply shocks explain 3 percent and 12 percent of the error variance of French exports and imports, respectively, demand shocks explain about 90 percent and 45 percent, respectively. In addition, confidence indicators and interest rates variance shares are relatively high. Consumer confidence matters most for the transmission of U.S. supply shocks, while long-term interest rates matter most for the transmission of U.S. demand shocks. It is noteworthy that U.S. demand shocks explain over 80 percent of the error variance of French long-term interest rates, which supports the strong business cycles links between France and the U.S. found in earlier empirical work (Kose and others, 2003; Nadal De Simone, 2003). ${ }^{17}$ Finally, while admittedly the variance share of the common components of stock prices is relatively low, their error variance following U.S. supply shocks is very large.

U.S. supply shocks seem to be transmitted negatively on French output. While French output seems negatively affected by U.S. supply shocks, with a median error variance of 23 percent over first five years, the outcome for that period is in fact statistically insignificant. ${ }^{18}$ The large variance share of the current account highlights the role of the trade channel. The current account moves into surplus as, although exports of goods and services fall in the short run, exports increase over time relatively more than imports. The terms of trade improve somewhat, and the real effective exchange rate appreciates marginally, given that the U.S. CPI falls more than the French CPI. While there is no lasting significant change in the real effective exchange, the transient fall in competitiveness magnifies the transmission of U.S. supply shocks. In addition, notice the negative effect on consumption and consumer confidence, consistent with the decline in employment and wages. Stock prices are affected positively and in lasting manner, which mimics their U.S. pattern. The downward impact effect on interest rates (especially short-term interest rates), possibly as a result of an accommodating action on the part of Euro area monetary policy makers, is relatively shortlived. Outward FDI flows are relatively more important than inward FDI flows for the transmission of supply shocks. Given that outward FDI flows decrease and that inward FDI flows increase, the (moderate) negative transmission of U.S. supply shocks to France may be a case of inter-industrial specialization driving trade patterns. ${ }^{19}$

\footnotetext{
17 These results are consistent with IMF (2001) and other studies (e.g., Anderton, di Mauro and Moneta, 2004), which stress the role of financial variables and confidence channels in the transmission of macroeconomic disturbances across countries. While in the words of Keynes, "The state of confidence...is a matter to which practical men always pay the closest and most anxious attention," economist have mostly avoided the issue. The profession has accepted that mood swings are difficult to explain. This paper uses generally accepted measures of confidence as "channels" through which views of the world unfold and affect, for instance, business investment decisions by mechanisms not yet fully identified.

18 This outcome is consistent with Eickmeier's (2004) results on the effects of the U.S. supply shock on German GDP; she finds a positive effect, which is nevertheless not statistically significant. The sign of output shocks transmission is controversial in the empirical literature: those who stress traditional trade channels of transmission posit that a supply shock, by boosting trading partners exports, is transmitted positively (e.g., Kose, Prasad, and Terrones, 2003). In contrast, those who stress inter-industrial specialization and FDI flows hypothesize a negative transmission (e.g., Imbs, 2004).

19 The variance share of these variables common components is low. Eickmeier (2004) reports similar results (for Germany).
} 
U.S. demand shocks get transmitted positively to France. Over the sample period, U.S. demand shocks of about 1 percent of GDP (over 20 quarters) have a significant positive impact on France's real GDP of about 0.5 percent. Exports of goods an services rise more than imports of goods an services in the first 4-6 quarters producing initially a small current account surplus, which turns into a deficit as imports remain high while the impulse on export fades. The terms of trade worsen, most likely due to the effect of the positive U.S. shock on global price variables such as oil and metal prices. The real effective exchange rate depreciates somewhat, especially during the first year, magnifying thereby the U.S. demand shocks' effects on activity (the counterpart of the U.S. real exchange rate appreciation). There is a lasting, albeit small, positive effect on both consumer and business confidence. Consumption and investment rise in response. Demand drives up French productivity, with benign effects on the price level. Both short- and long-term interest rates increase, most likely as a result of Euro area monetary policy trying to avoid that employment and wage growth translate into inflationary pressures. Stock prices matter relatively little. Finally, in contrast to supply shocks, outward FDI flows are relatively less important than outward FDI flows. In addition, and also in contrast to the effects of U.S. supply shocks, FDI inflows decline, which is difficult to rationalize.

U.S. shocks affect EU member countries asymmetrically. ${ }^{20}$ A comparison of the variance shares and error variances of French and German variables reveals a few noteworthy points, several of them important to judge the relative flexibility of the two countries' product and labor markets. First, the variance share of the common components of German GDP is 78 percent against 43 percent in the case of France, a likely outcome of the relatively larger openness of the German economy. However, U.S. shocks affect French output more than German output: U.S. supply and demand shocks affect German GDP less than 1 percent and about 7 percent, respectively, against 23 percent and 34 percent, respectively, in the French case. Second, France responds relatively less to U.S. supply shocks than Germany, at least judging from the relatively lower error variance of prices, employment and productivity, and the real exchange rate. France's response to U.S. demand shocks is, in contrast, more pronounced than Germany's. This is illustrated by the relatively high error variance of wages and employment as well as the real exchange rate. ${ }^{21}$ Third, while the consumer confidence channel seems to matter much more for the transmission of U.S. supply shocks to France than to Germany, stock prices matter more for the transmission of U.S. demand shocks to Germany. Finally, the variance share and the error variance of FDI inflows suggest that they

\footnotetext{
${ }^{20}$ The presence of asymmetries in business cycle behavior across countries is well known (e.g., Nadal De Simone, 2007, forthcoming).

${ }^{21}$ On the one hand, it is not immediately clear why the response of the French economy to U.S. supply and demand shocks differ. A possible reason may be the relatively more important role played by the real sector in the transmission of demand shocks, and the shorter duration of the required changes in the production structure than ensues. Those short-term adjustments to production can be undertaken without changes in capacity and long-term employment. On the other hand, in the literature on optimum currency areas, price and wage flexibility was one key mechanism by which the costs of losing the monetary policy tool by joining a currency area could be diminished. The shock often assumed in that strand of literature was a supply-side shock, i.e., a change in preferences or technology. On this vein, this paper results seem to suggest that the French economy has less price flexibility than the German economy. This is, however, an issue for further research.
} 
matter relatively more for Germany than for France as channels of transmission of U.S. supply shocks.

\section{Is There Evidence of Increasing Interdependence Among Countries?}

French interdependence has increased over time. The results of the estimation of the model using the time period 1990:Q1-2003:Q4 show that, as might be expected, France experienced a strengthening of its linkages and interdependence with the rest of the world during the last decade or so. While the total error variance of French GDP explained by U.S. shocks in the full sample period is 57 percent, it increases to 82 percent when the reduced sample period is used (Table 3 ). ${ }^{22}$ That increase basically took place through a significant relative rise in the role of U.S. demand shocks. The relative importance of channels of transmission also changed. Besides the enhanced role of the stock market channel in more recent times, confidence channels (notably business confidence) increased their significance. ${ }^{23}$ Consistently, the impact of investment in explaining activity fluctuations in France also rose, albeit in tandem with the increase in the share of common components in the error variance of French GDP. Finally, it also seems that France's capacity to adjust to U.S. supply shocks improved somewhat while its capacity to adjust to U.S. demand shocks became more difficult. Note, in particular, the relatively higher (lower) variance of prices that U.S.-driven supply (demand) shocks explain in the reduced sample period. The error variances of the real effective exchange rate display similar changes. Seemingly, the observed increase in the error variances of wages was not sufficient.

Adjustment to U.S. shocks varies across countries. When France is compared with Germany, a few points merit stressing. First, it is noticeable that the error variance of French price variables is in general lower than German variables following U.S. (especially supply) shocks (e.g., compare the error variances of prices, wages and the real exchange rate on Table 3a for France and on Table 3b for Germany). ${ }^{24}$ Consistently, employment does relatively more of the adjustment to U.S. supply shocks in France than in Germany. Second, the adjustment via short-term interest rates following U.S. demand shocks is more significant for Germany than for France. Finally, confidence channels matter for U.S. supply shocks relatively more in France and for U.S. demand shocks relatively more in Germany.

The predominant role played by U.S. shocks is also clear in the shorter sample period. With data available for 1991:Q1-2003:Q4 for broader aggregates of global and regional economic activity, the paramount role of U.S. shocks seems confirmed. When the shock is to G7 economic activity (excluding France), the error variance of French GDP explained increases to 82 percent ( 25 percentage points more than when shocks are from the United

\footnotetext{
${ }^{22}$ It also increases in the German case: it rises to about 96 percent from just 7 percent in the full sample. This is most likely the result of the significant output effects of German unification, which may have blurred the underlying forces of economic integration of the German economy into the world.

${ }^{23}$ These results are consistent with IMF (2001) that reports a growing importance of financial variables in the transmission of shocks across countries over time.

${ }^{24}$ Compared to wages behavior in the full sample, French wages variance following U.S. shocks increased somewhat.
} 
States, in the period 1980-2003). These results further stress the large role played by U.S. shocks in international business cycles.

There is limited evidence of relatively minor "regional shocks." When the shock is to the euro area activity measure (excluding France), the error variance of French GDP explained also rises to 64 percent (Table 4). The cross-spectrum of EU and French GDP common components is broadly similar to the one of U.S. and French GDP common components (Figure 2), with one important caveat: only EU GDP common components lead France's common components in the very long run. In addition, the cross-spectrum of U.S. and EU GDP common components shows that the U.S. leads the EU (Figure 3) in periodicities ranging between 7 and 128 quarters. The results suggest there may be some role for "regional factors" in explaining the error variance of French GDP, but that role can be tentatively considered small. This finding is broadly consistent with several studies pointing to a relatively minor role to regional factors (e.g., Kose, Otrok, and Whiteman, 2003; and Nadal De Simone, 2003). Summarizing all cross-spectrum results, the analysis indicates: (1) only the U.S. leads France in periodicities ranging between 8 quarters and 15 quarters; (2) the EU and the U.S. together lead France in periodicities ranging between 16 and 128 quarters and; (3) the EU and France comove in the very long run.

Asymmetries in business cycle transmission persist during the shorter sample period. U.S. and G7 economic activity affect French output relatively more via demand shocks, while euro area activity affects French output relatively more via supply shocks. This is likely the outcome of the relatively richer vertical and horizontal integration between French and regional firms than between French and G7 firms - other than euro area. As an illustration, the supply shocks from the euro area aggregate explain a significantly larger share of the error variance of exports of goods and services than the G7 shocks or the U.S. shocks (i.e., 66 percent versus 6 percent and 16 percent, respectively). Similarly, the large increase in the error variance of French confidence variables (especially business confidence) when the shock is to euro area activity, further indicates the likely presence of a regional factor which, albeit seemingly small, deserves further analysis.

\section{ConClusion AND Policy Implications}

While certainty about the sources of shocks is not easily achievable, there is strong evidence that French output behavior is significantly affected by U.S. shocks. This study found that U.S. shocks, especially demand shocks, seem to play an important role in explaining the behavior of French economic activity. International trade in goods and services, the terms of trade, the real effective exchange rate, and FDI flows are the main channels of transmission of U.S. demand and supply shocks. Financial variables, such as interest rates, are also important. The stock market and consumer confidence channels seem relatively more relevant for the transmission of U.S. supply shocks, with interest rates instead being relatively more important for the transmission of demand shocks. There still remains a significant role for idiosyncratic components to contribute to the explanation of French output fluctuations, but relatively less than in the German case, especially when the period considered excludes the 1980s. This indicates that French economic policies do matter. 
France has become more integrated to the world economy over time. The interdependence of the French economy has increased over time, and the role of financial variables as channels of transmission of shocks has become relatively more important. The increased importance of the business confidence channel is also noteworthy (at least judging from the increase in the variance share of the common components). In addition, and compared to Germany, the French economy reacts (especially) to U.S. supply shocks relying relatively more on employment and real exchange rate changes than on price changes.

U.S. shocks explain a larger part of French output common components than a broader aggregate of economic activity. While the use of a broader aggregate of economic activity than just U.S. real GDP increases the importance of the common components in explaining French economic activity fluctuations, the bulk of output variance can already be captured by a pair of distinctively U.S. shocks. This seems especially the case for the post-1990 period. The results stress the important role played by fluctuations in U.S. economic activity in explaining French economic fluctuations.

However, given that idiosyncratic components do matter in explaining French output fluctuations, the French economy would benefit from further structural reforms that increase its flexibility. The importance of trade flows and relative price changes in the international transmission of disturbances highlights the relevance of domestic price flexibility. As the results of the paper suggest, following U.S. supply shocks, the speed of adjustment of French prices relative to U.S. prices is lower. This will matter for the magnitude of the real effective exchange rate changes, trade flows, and the size of the current account balance that will be necessary to accommodate the given disturbance. Similarly, following shocks in the United States, it is likely that, ceteris paribus, the level of interest rates consistent with macroeconomic stability in France will be higher the less flexible the economy is; this seems to be the case given the larger variance share of long-term interest rates in France than in Germany. These conclusions are hardly unexpected, but the framework used in this paper has evinced, in a robust way, their policy relevance.

The asymmetry in the transmission of U.S. shocks to EU members further supports calls to increase market's flexibility. The asymmetry in the transmission of shocks across countriesillustrated here by comparing French and German variables' responses to U.S. shockstogether with the predominant role that exogenous factors play in the dynamics of French output, argue for domestic policies geared toward boosting goods, services, and labor markets flexibility in France. 
Figure 1. Impulse-Response Functions Full sample-1980:Q1-2003:Q4 (482 series)

Supply Shock (USA)
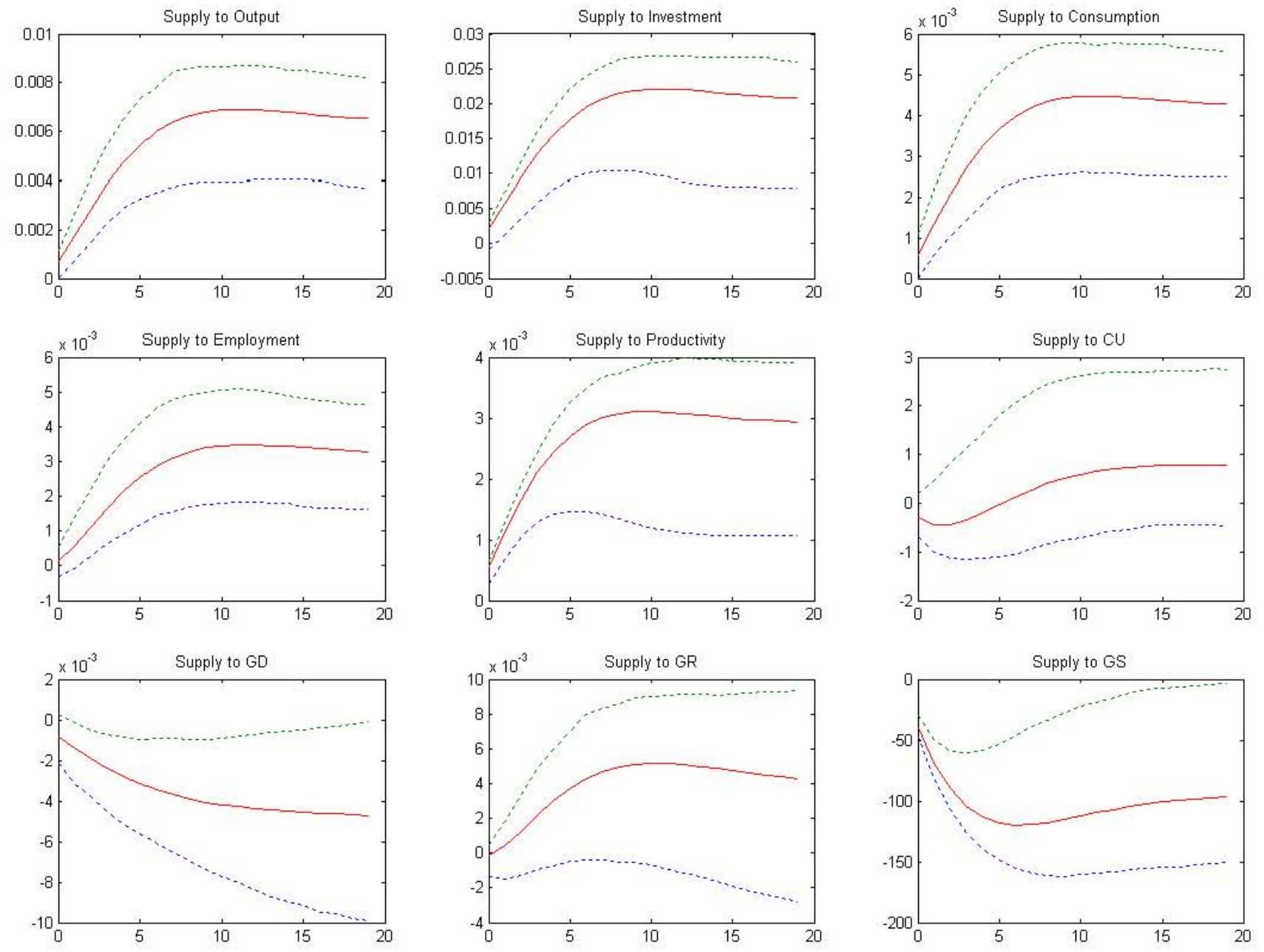

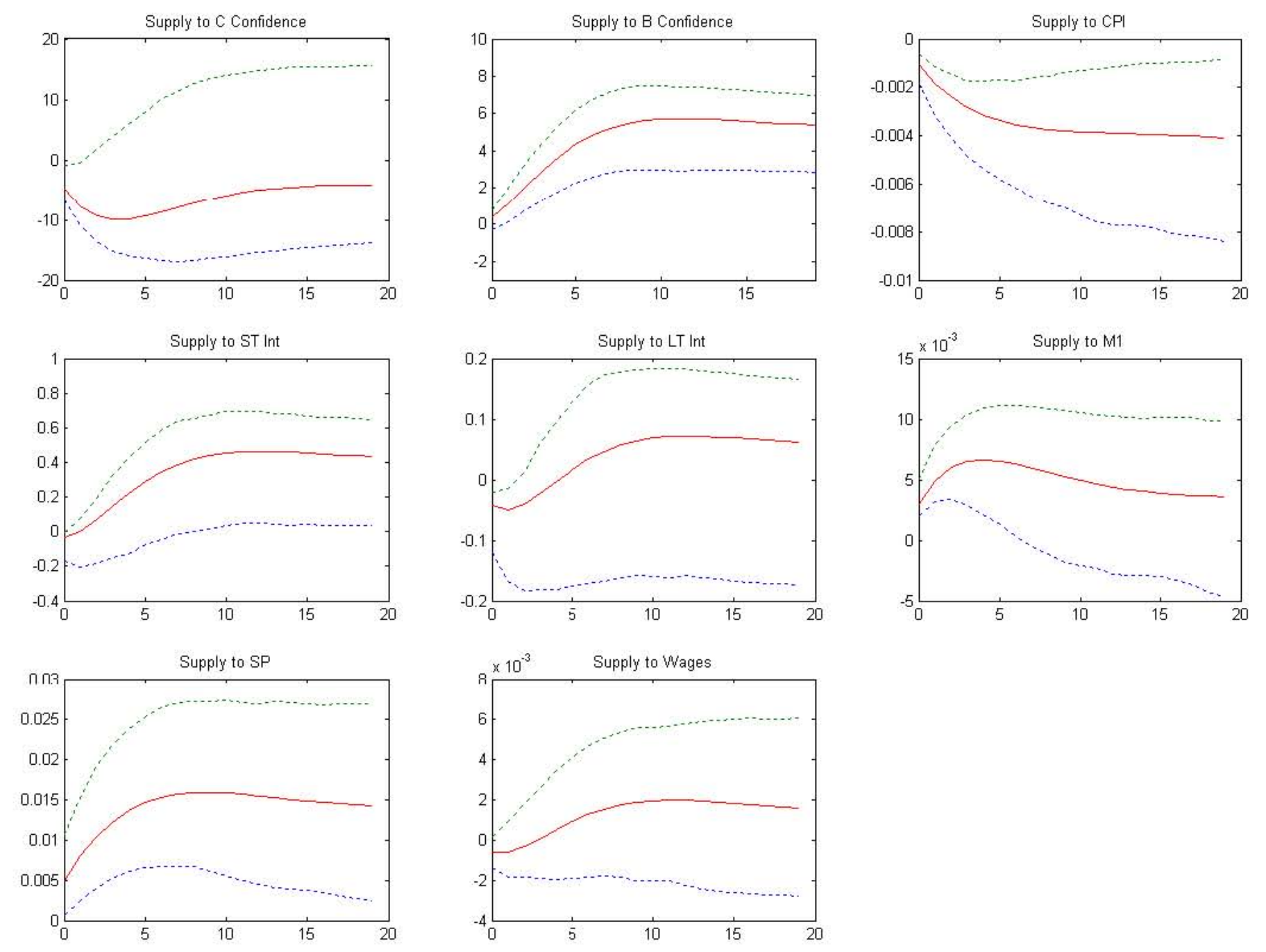

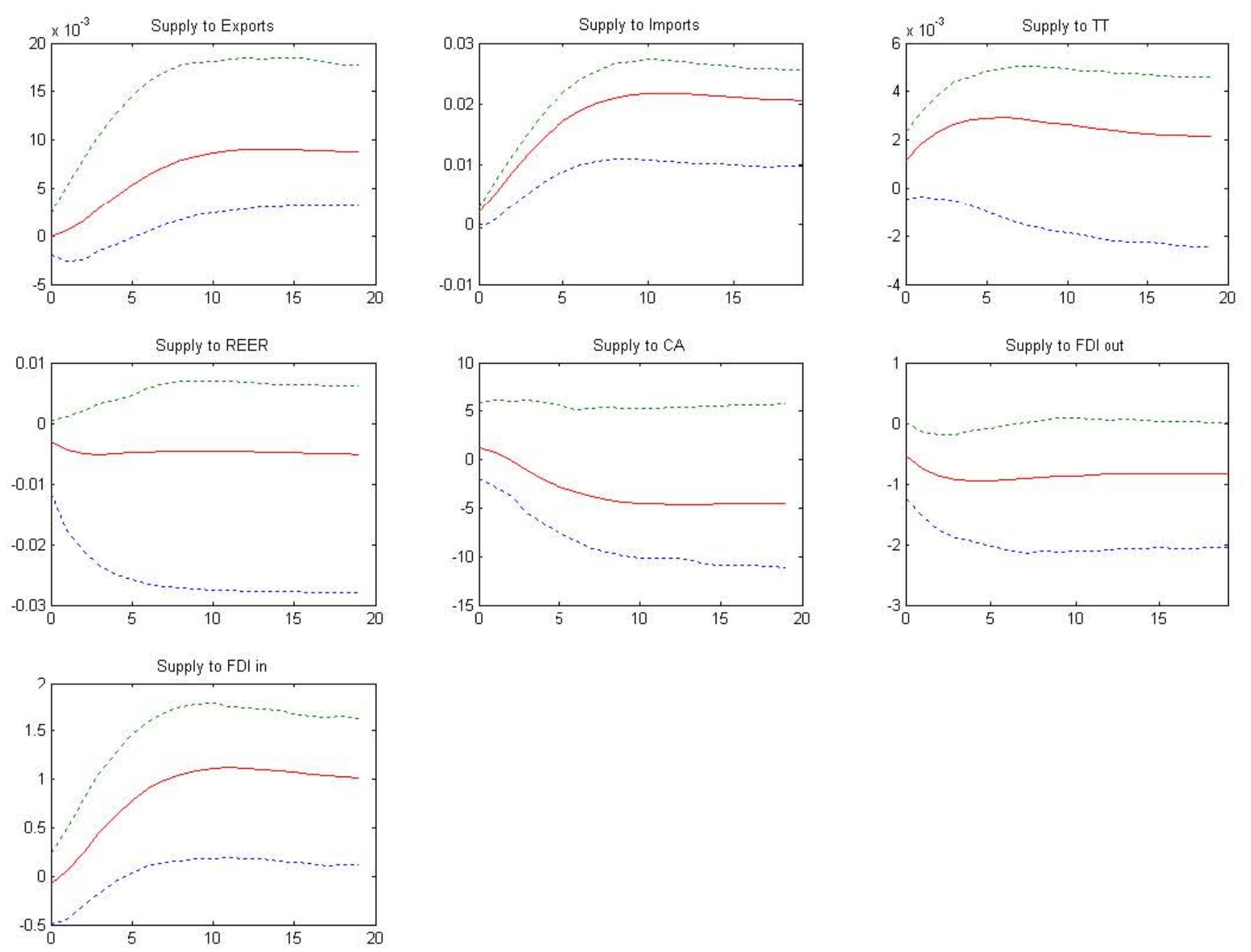
Demand Shock (USA)
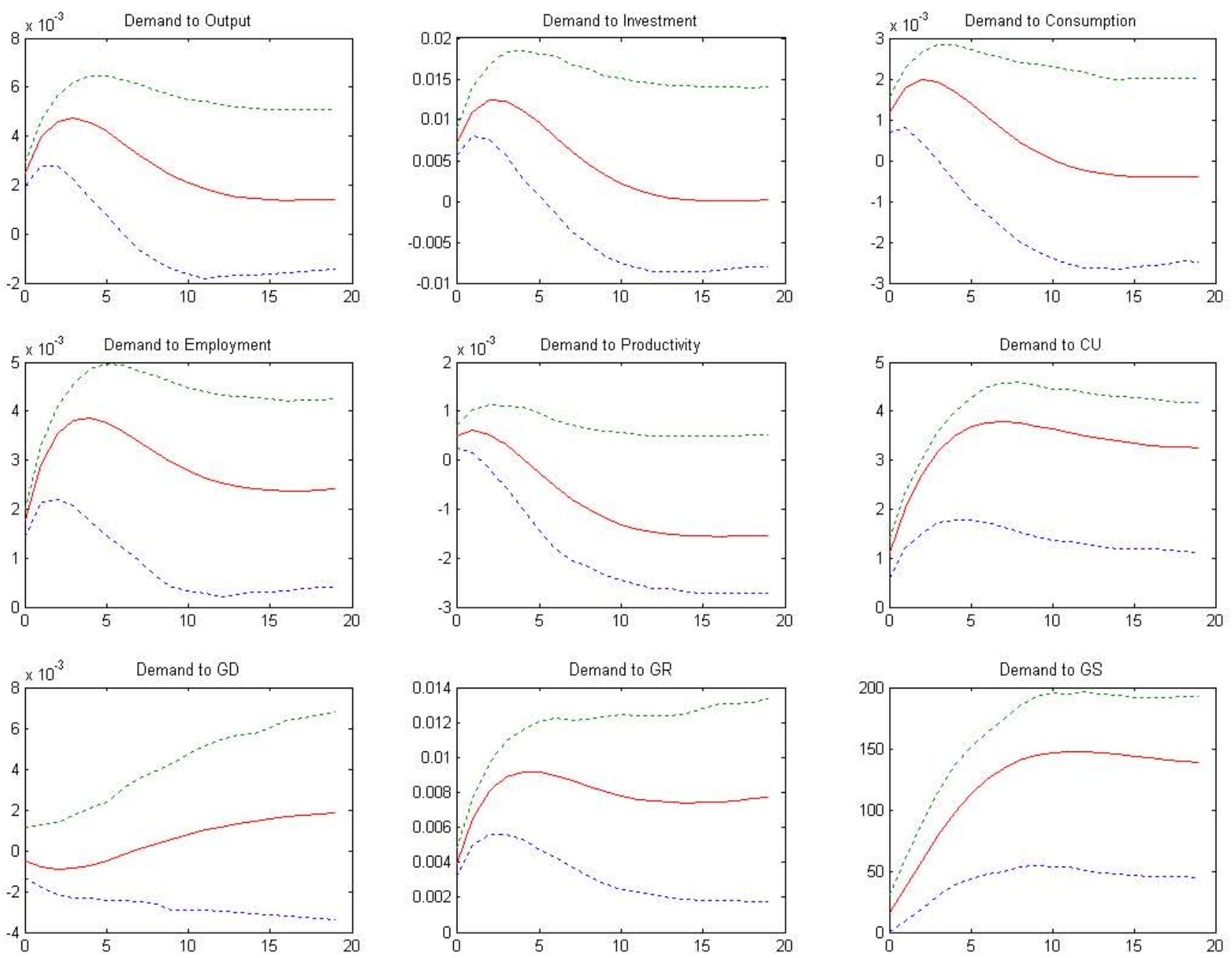

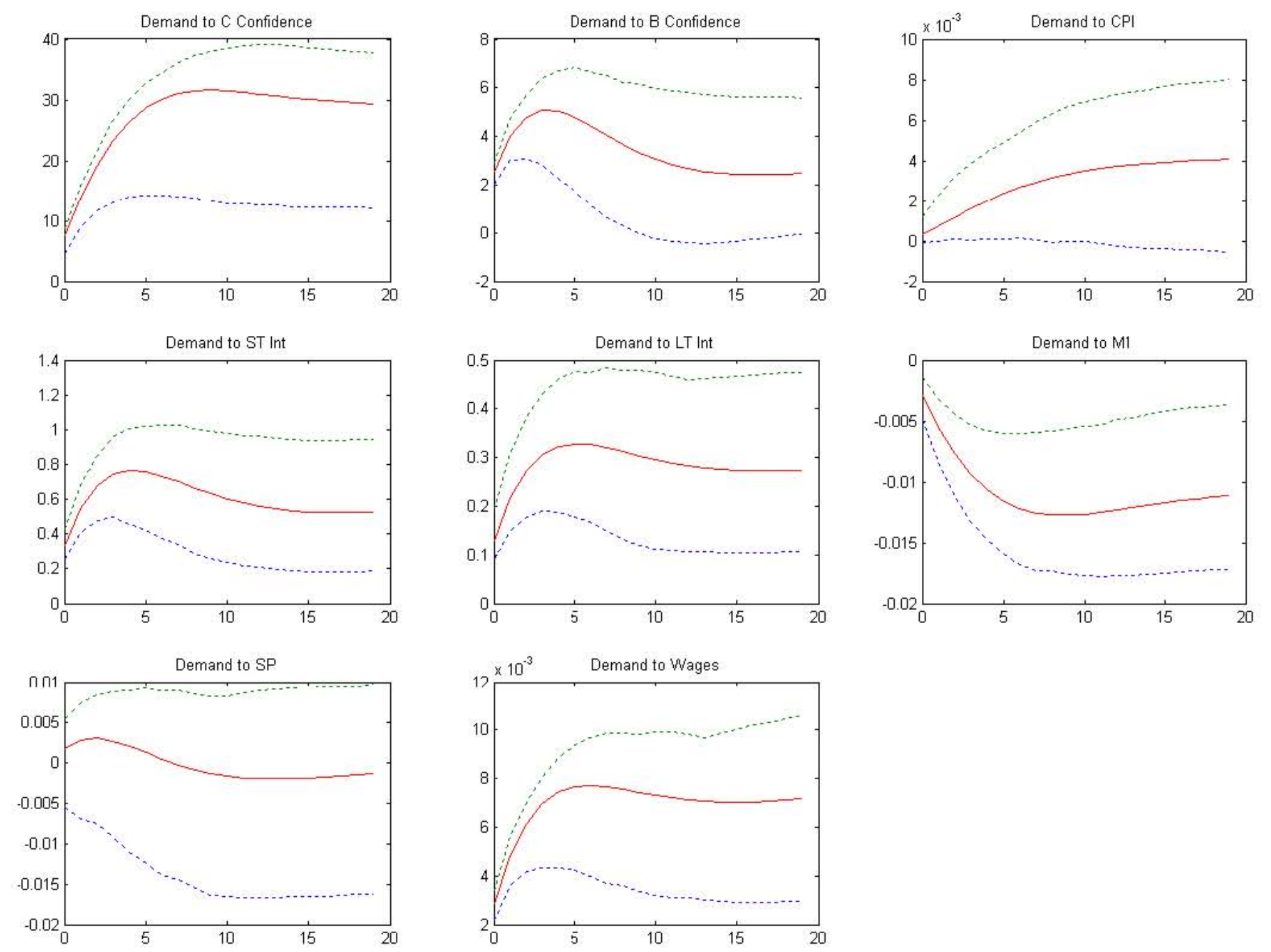

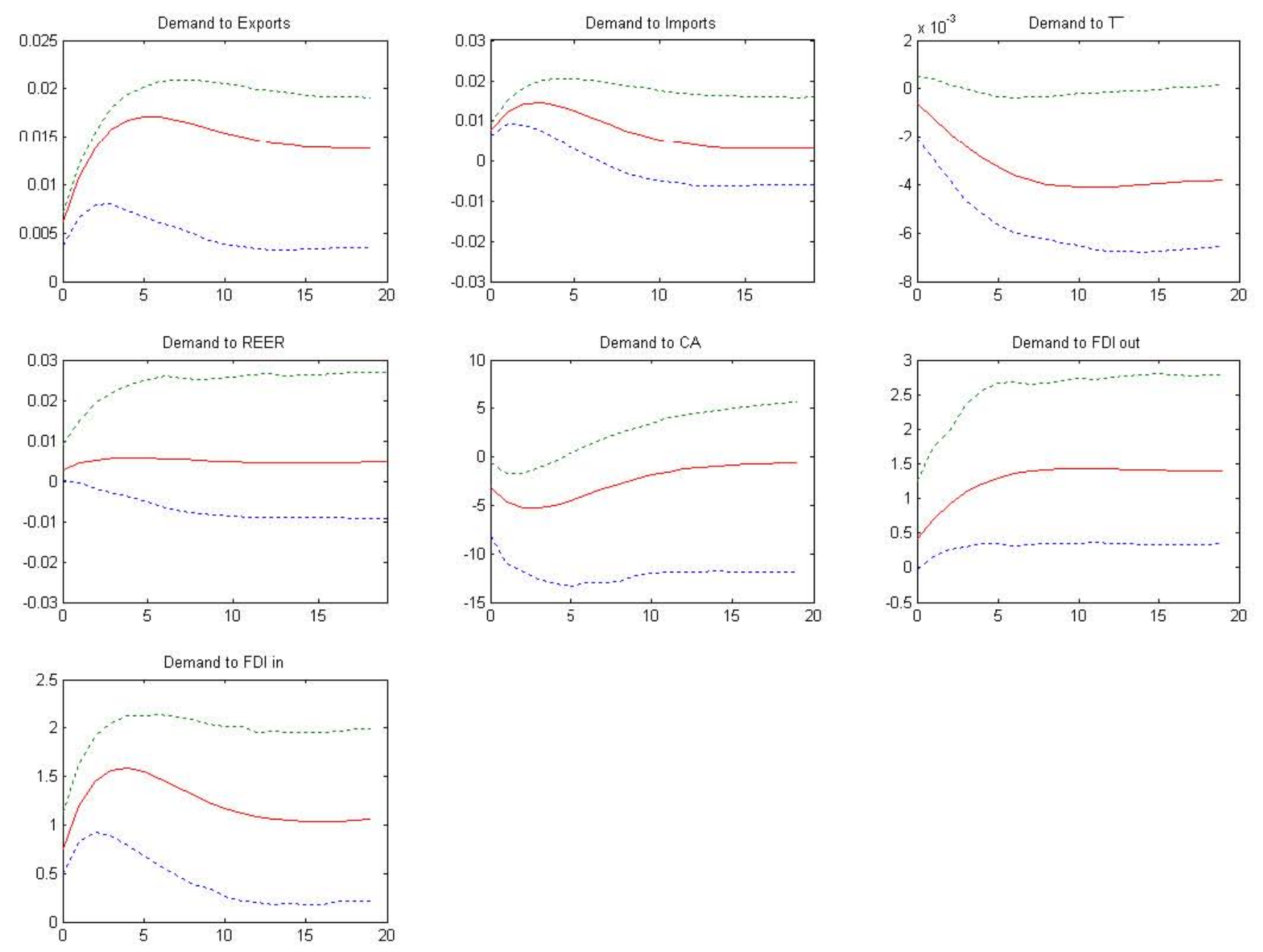


\section{Supply Shock (France)}
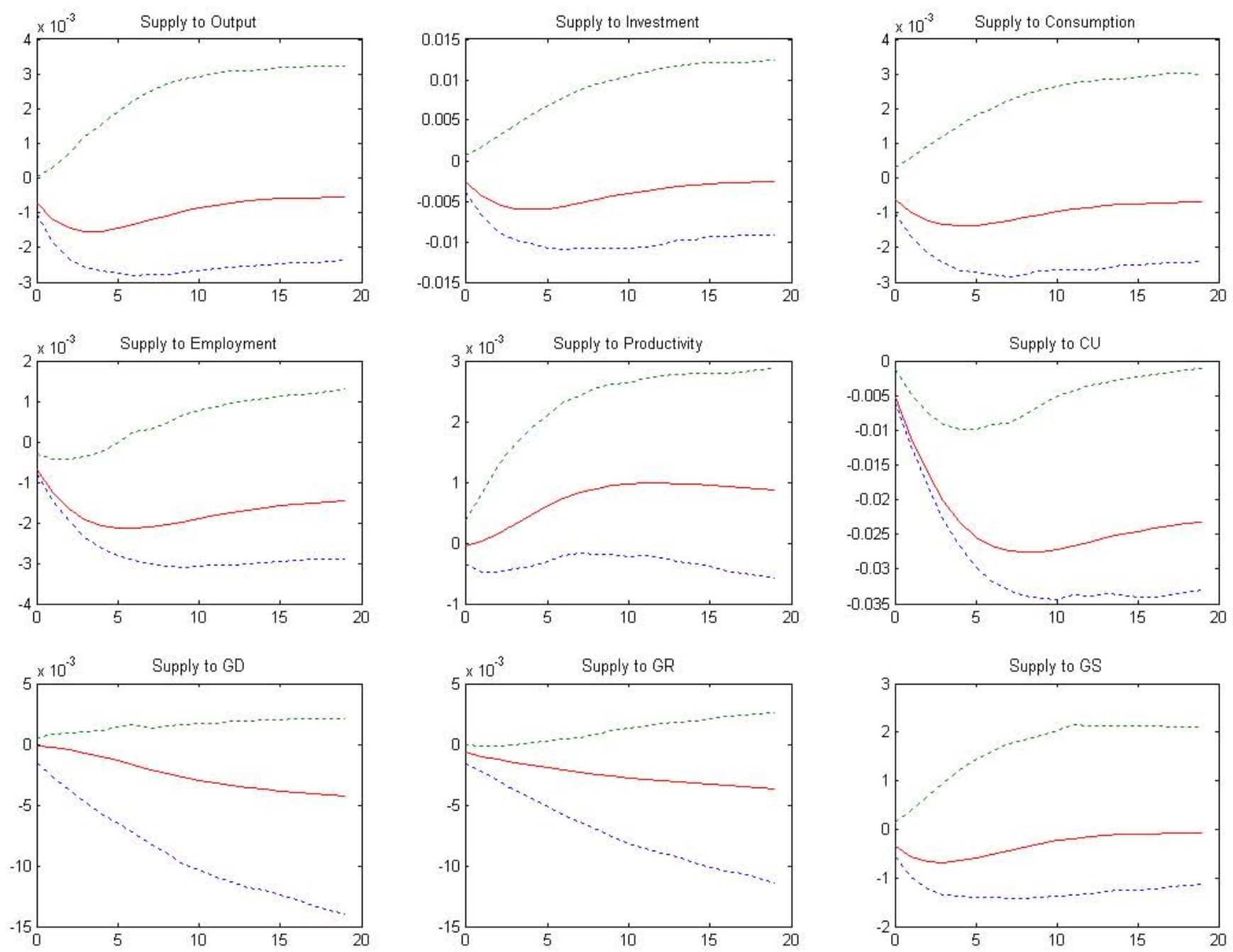

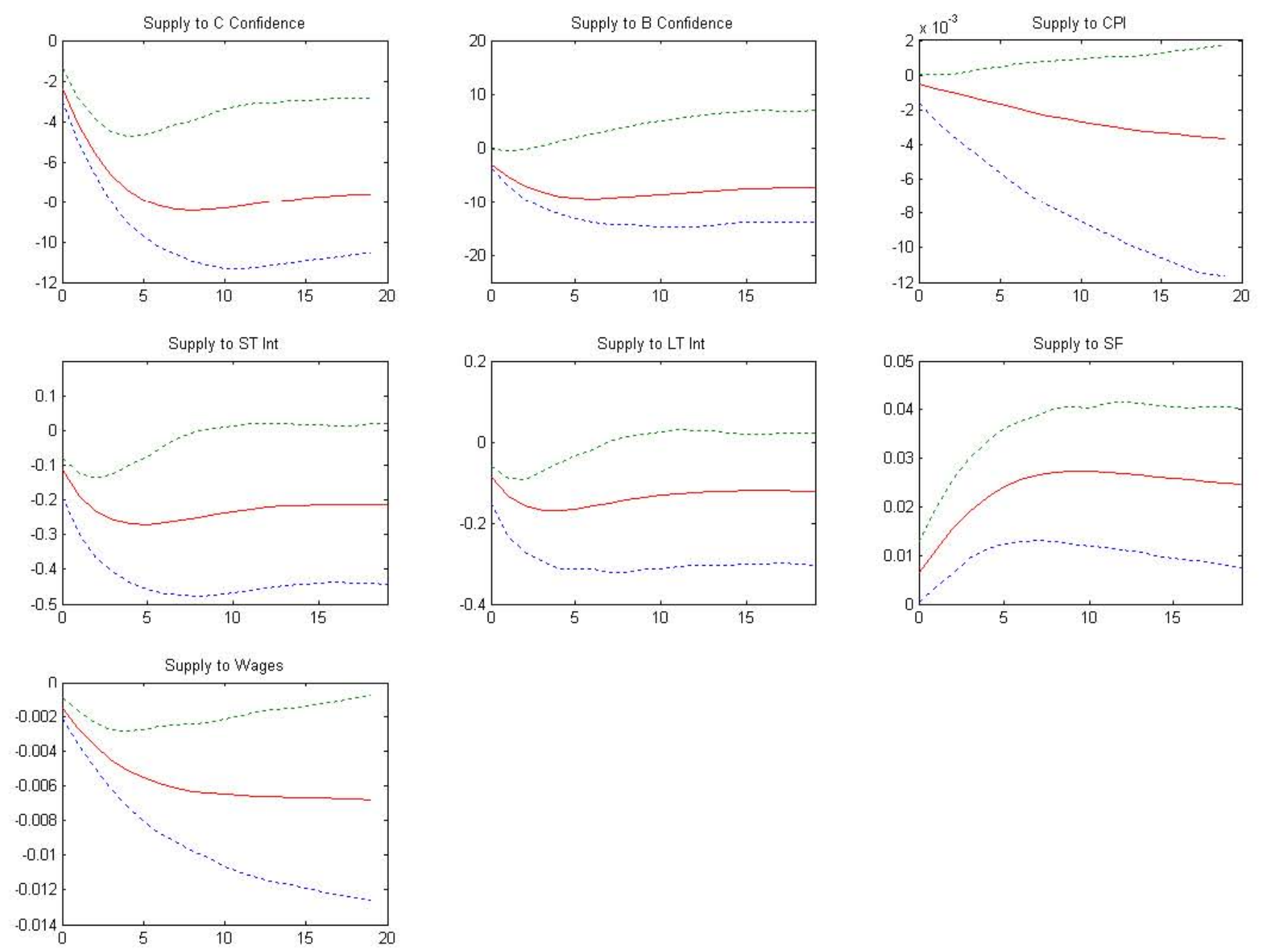

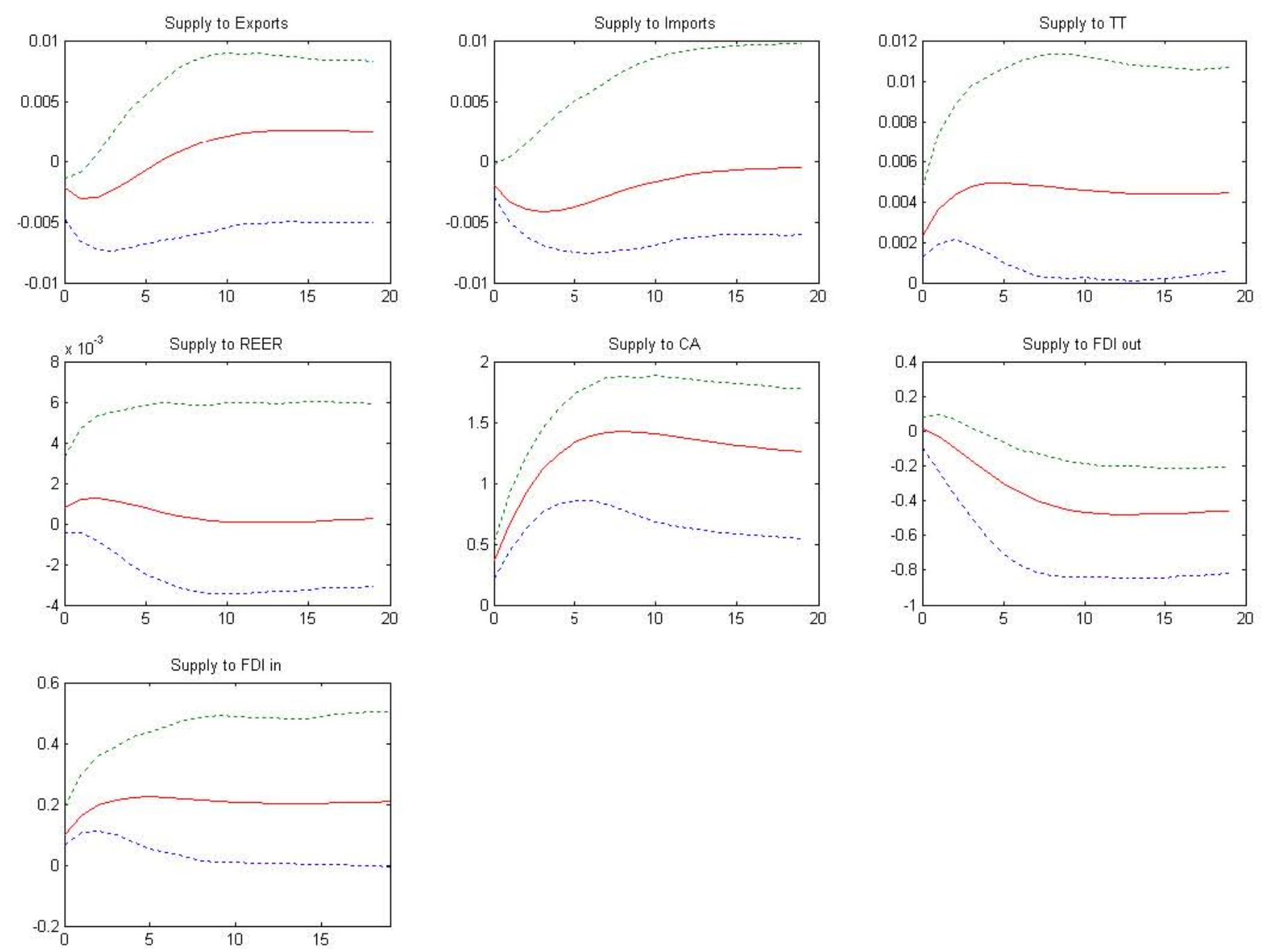
Demand Shock (France)
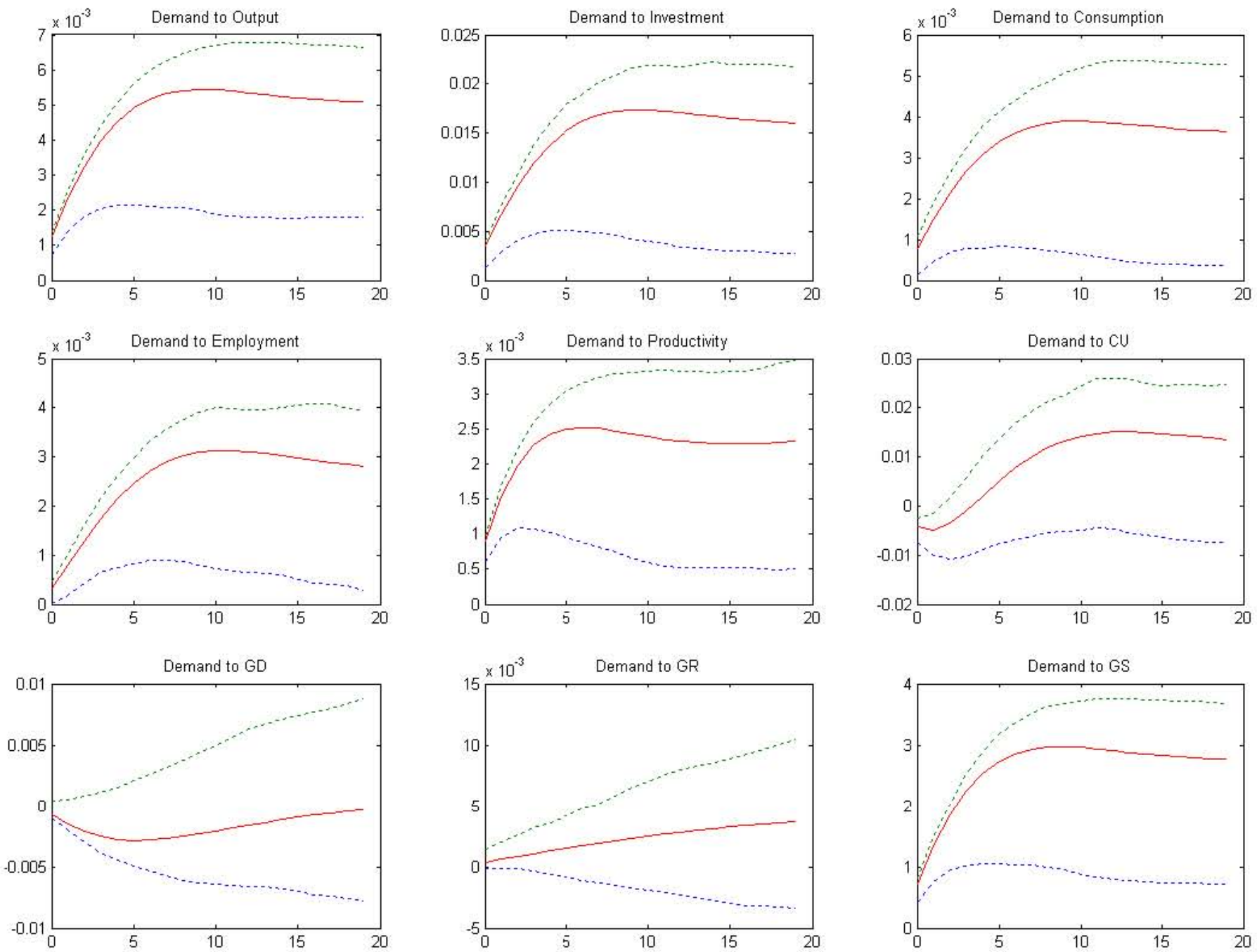

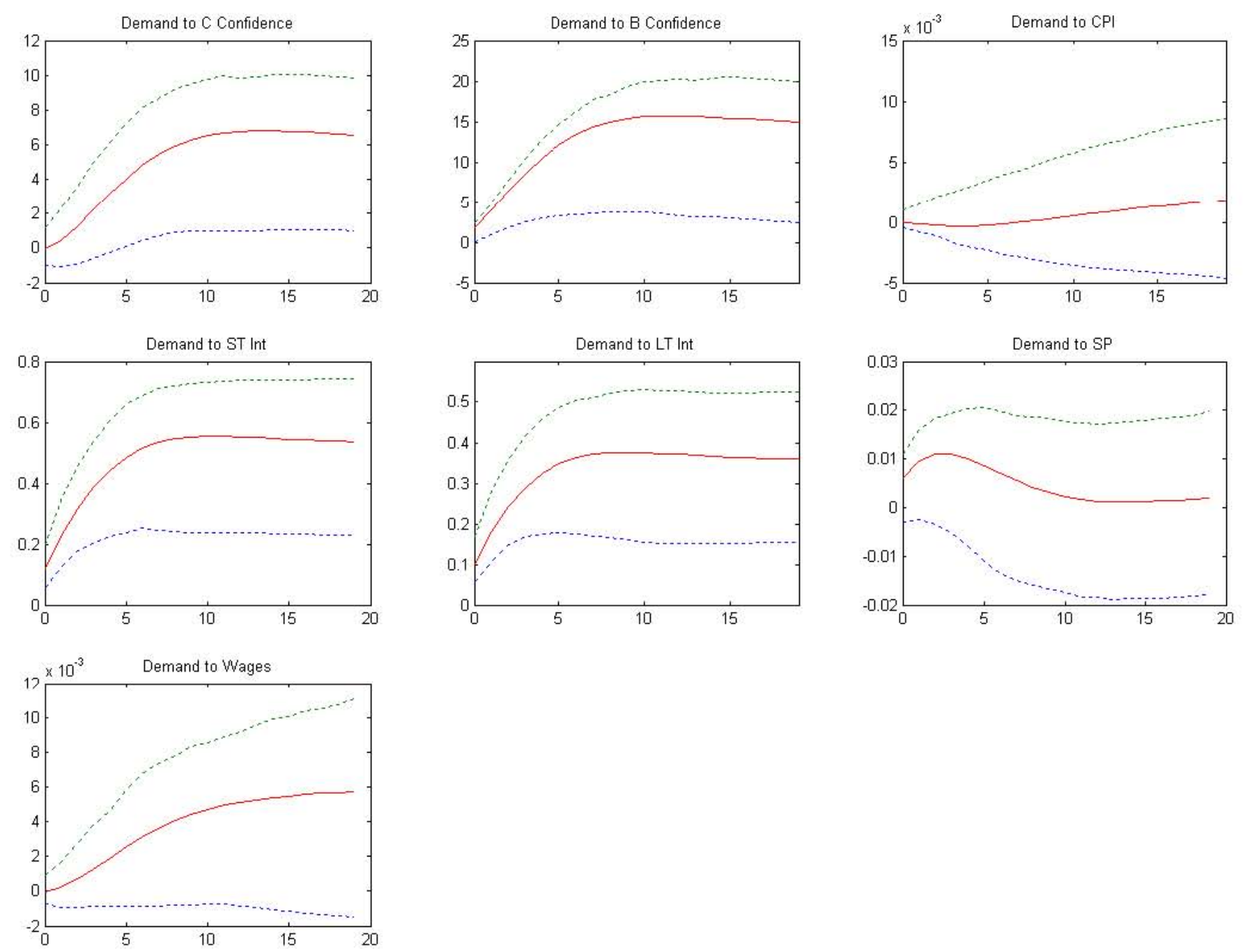

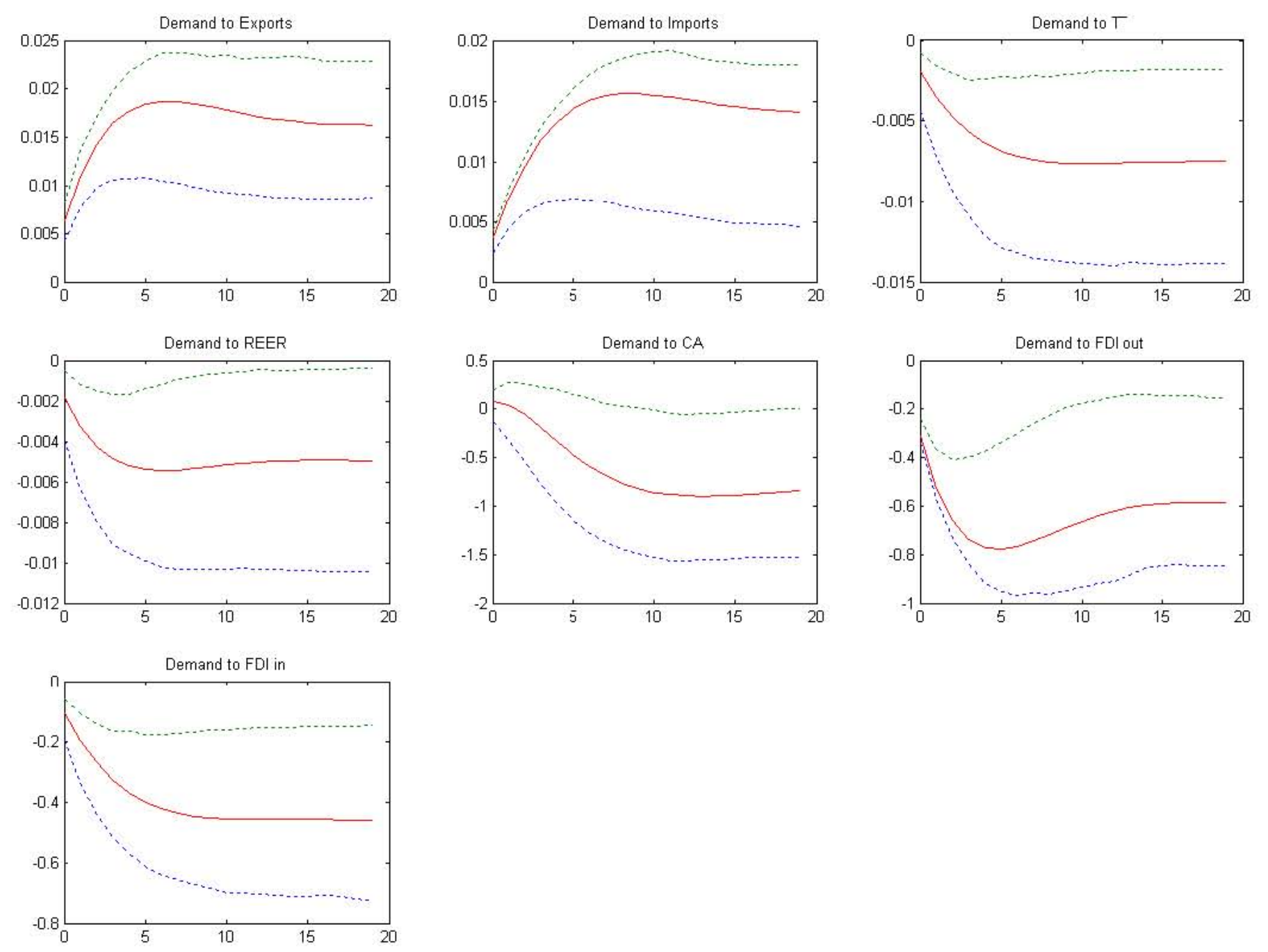


\section{Acronyms}

$\begin{array}{ll}\text { CU } & \text { Capacity utilization } \\ \text { GD } & \text { Government current disbursements } \\ \text { GR } & \text { Government current receipts } \\ \text { GS } & \text { Government net savings } \\ \text { C Confidence } & \text { Consumer confidence } \\ \text { B Confidence } & \text { Business confidence } \\ \text { CPI } & \text { Consumer price index } \\ \text { ST Int } & \text { Short-term interest rate } \\ \text { LT Int } & \text { Long-term interest rate on government bonds } \\ \text { SP } & \text { Share price index } \\ \text { TT } & \text { Terms of trade } \\ \text { REER } & \text { Real effective exchange rate } \\ \text { CA } & \text { Current account of the balance of payments } \\ \text { FDI } & \text { Foreign direct investment flows }\end{array}$


Figure 2. Common Components: Q2 1991 - Q4 2003

Shocks: USA GDP and EU (excluding France) GDP
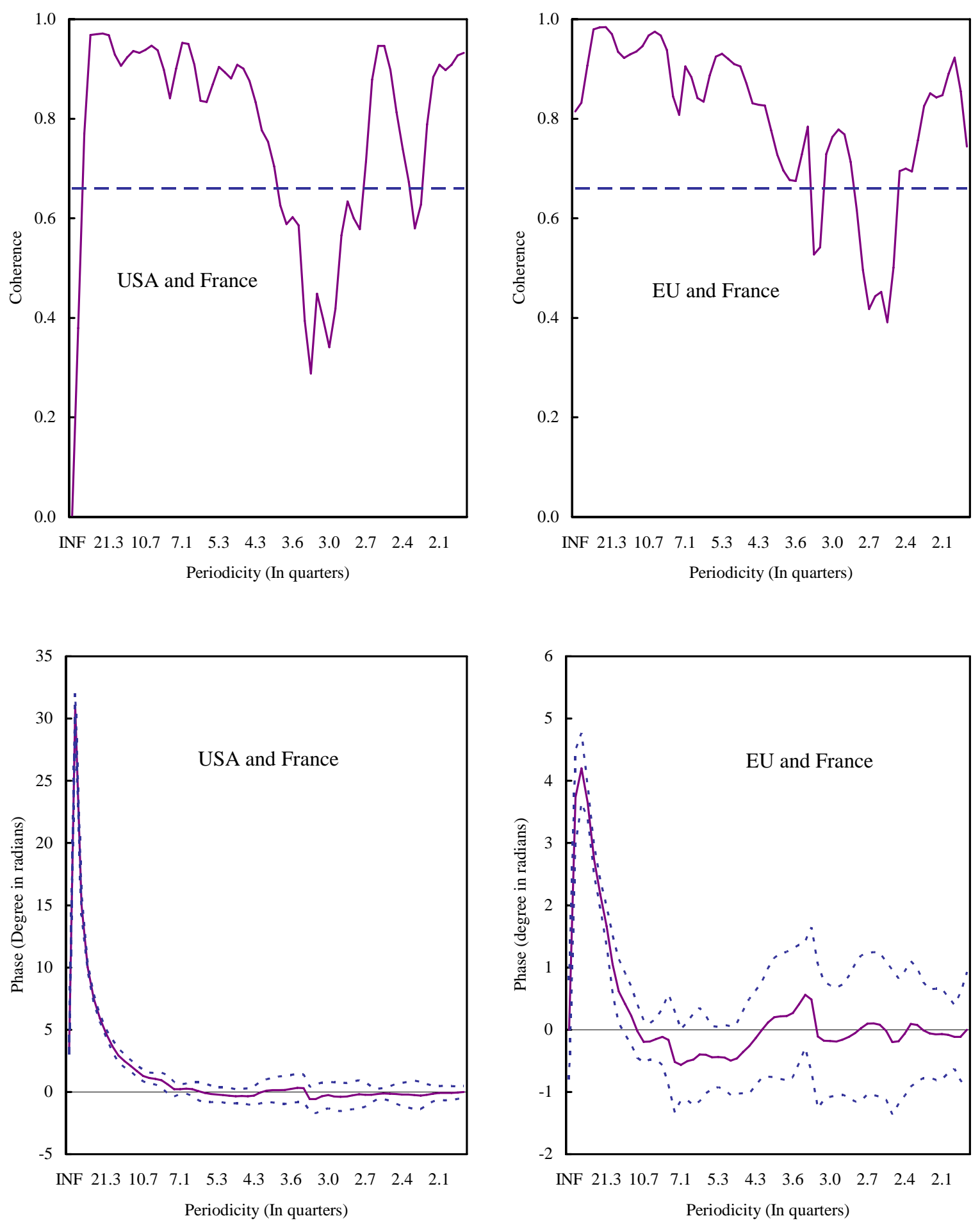

Source: Staff estimates. 
Figure 3. Common Components: Q2 1991 - Q4 2003

Shocks: USA GDP and EU (excluding France) GDP
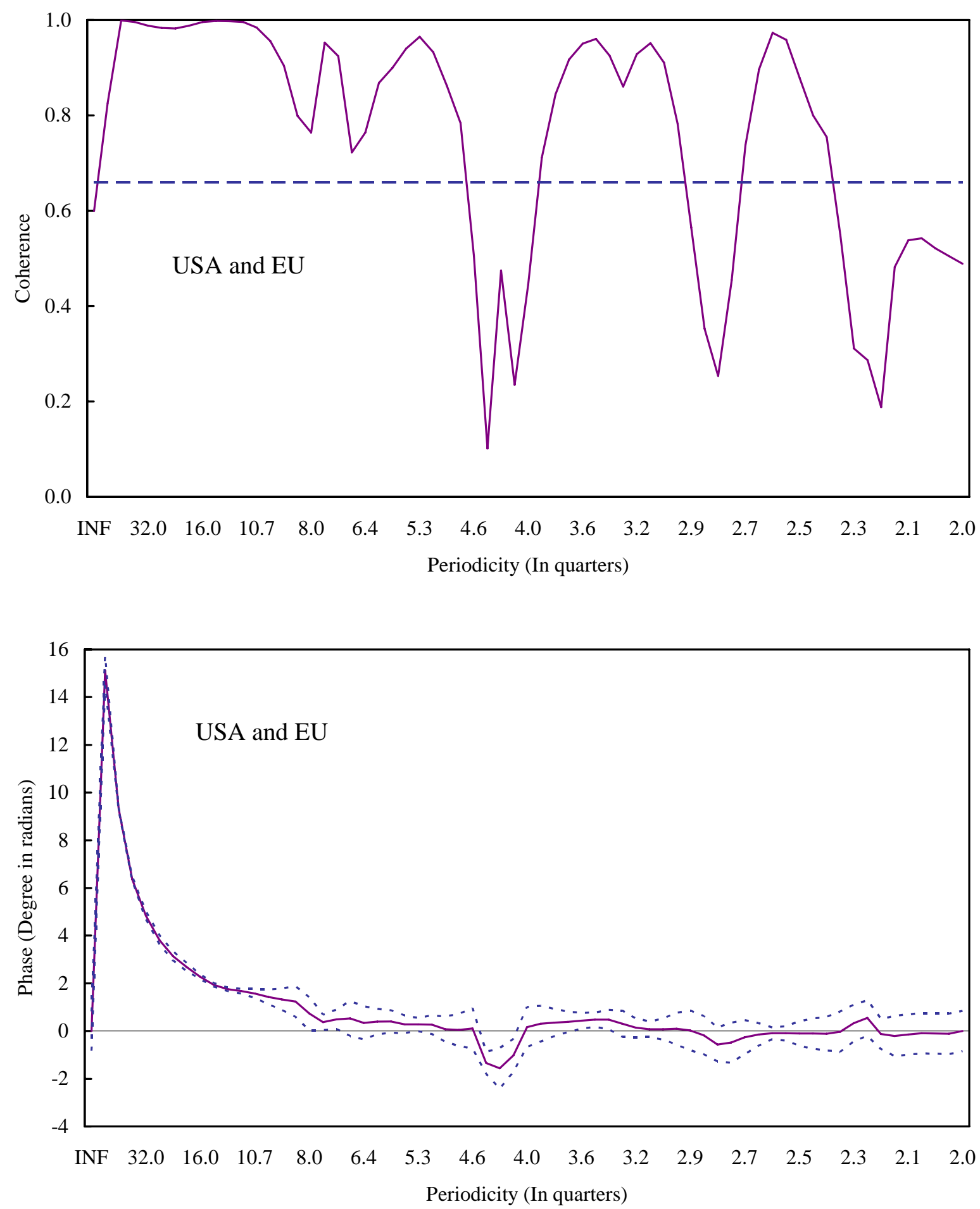

Source: Staff estimates. 
Table 1a. Forecast Error Variance of the Common Components of USA Variables Explained by the USA Supply Shock and the Demand Shock, 1980-2003 1/

\begin{tabular}{|c|c|c|c|c|c|c|c|}
\hline & \multirow{2}{*}{$\begin{array}{r}\text { Variance Shares } \\
\text { of the Common } \\
\text { Components }\end{array}$} & \multirow{2}{*}{$\begin{array}{l}\text { Supply } \\
\text { Shocks }\end{array}$} & \multicolumn{2}{|c|}{ Confidence Intervals } & \multirow{2}{*}{$\begin{array}{l}\text { Demand } \\
\text { Shock }\end{array}$} & \multicolumn{2}{|c|}{ Confidence Intervals } \\
\hline & & & Lower Bound & Upper Bound & & Lower Bound & Upper Bound \\
\hline GDP & 0.54 & 0.87 & 0.30 & 0.92 & 0.11 & 0.05 & 0.67 \\
\hline Private investment & 0.62 & 0.71 & 0.22 & 0.85 & 0.19 & 0.05 & 0.58 \\
\hline Personal consumption expenditure & 0.32 & 0.87 & 0.40 & 0.93 & 0.04 & 0.02 & 0.33 \\
\hline Employment & 0.60 & 0.75 & 0.11 & 0.82 & 0.21 & 0.12 & 0.83 \\
\hline Productivity & 0.14 & 0.67 & 0.21 & 0.94 & 0.06 & 0.01 & 0.39 \\
\hline Capacity utilization & 0.48 & 0.12 & 0.01 & 0.37 & 0.61 & 0.28 & 0.91 \\
\hline Government current disbursements & 0.58 & 0.03 & 0.01 & 0.57 & 0.02 & 0.00 & 0.21 \\
\hline Government current receipts & 0.25 & 0.34 & 0.00 & 0.37 & 0.39 & 0.15 & 0.77 \\
\hline Consumer confidence & 0.66 & 0.11 & 0.01 & 0.32 & 0.50 & 0.32 & 0.91 \\
\hline Business confidence & 0.74 & 0.74 & 0.15 & 0.86 & 0.24 & 0.09 & 0.79 \\
\hline Consumer prices & 0.71 & 0.24 & 0.04 & 0.64 & 0.46 & 0.00 & 0.48 \\
\hline Short-term interest rates & 0.36 & 0.15 & 0.01 & 0.48 & 0.83 & 0.22 & 0.90 \\
\hline Long-term interest rates & 0.37 & 0.02 & 0.00 & 0.18 & 0.95 & 0.16 & 0.85 \\
\hline M1 & 0.44 & 0.19 & 0.02 & 0.38 & 0.60 & 0.11 & 0.81 \\
\hline Stock prices & 0.09 & 0.56 & 0.04 & 0.75 & 0.02 & 0.00 & 0.25 \\
\hline Wages & 0.32 & 0.31 & 0.00 & 0.28 & 0.42 & 0.27 & 0.88 \\
\hline Exports total & 0.38 & 0.58 & 0.01 & 0.65 & 0.28 & 0.14 & 0.88 \\
\hline Imports total & 0.45 & 0.71 & 0.22 & 0.85 & 0.24 & 0.06 & 0.66 \\
\hline Terms of trade & 0.13 & 0.04 & 0.01 & 0.47 & 0.01 & 0.01 & 0.50 \\
\hline Real effective exchange & 0.45 & 0.39 & 0.00 & 0.53 & 0.54 & 0.00 & 0.40 \\
\hline Current account balance & 0.31 & 0.05 & 0.00 & 0.46 & 0.03 & 0.01 & 0.37 \\
\hline FDI out & 0.03 & 0.04 & 0.01 & 0.56 & 0.26 & 0.02 & 0.57 \\
\hline FDI in & 0.00 & 0.42 & 0.01 & 0.50 & 0.35 & 0.19 & 0.86 \\
\hline
\end{tabular}

Table 1b. Forecast Error Variance of the Common Components of France Variables Explained by the USA Supply Shock and the Demand Shock, 1980-2003 1/

\begin{tabular}{|c|c|c|c|c|c|c|c|}
\hline & \multirow{2}{*}{$\begin{array}{r}\text { Variance Shares } \\
\text { of the Common } \\
\text { Components }\end{array}$} & \multirow{2}{*}{$\begin{array}{l}\text { Supply } \\
\text { Shock }\end{array}$} & \multicolumn{2}{|c|}{ Confidence Intervals } & \multirow{2}{*}{$\begin{array}{l}\text { Demand } \\
\text { Shock }\end{array}$} & \multicolumn{2}{|c|}{ Confidence Intervals } \\
\hline & & & Lower Bound & Upper Bound & & Lower Bound & Upper Bound \\
\hline GDP & 0.43 & 0.23 & 0.01 & 0.30 & 0.34 & 0.22 & 0.85 \\
\hline Private investment & 0.67 & 0.28 & 0.01 & 0.35 & 0.11 & 0.08 & 0.74 \\
\hline Personal consumption expenditure & 0.20 & 0.40 & 0.00 & 0.36 & 0.02 & 0.04 & 0.66 \\
\hline Employment & 0.65 & 0.06 & 0.01 & 0.51 & 0.20 & 0.05 & 0.66 \\
\hline Productivity & 0.22 & 0.60 & 0.00 & 0.47 & 0.11 & 0.09 & 0.73 \\
\hline Capacity utilization & 0.57 & 0.53 & 0.07 & 0.72 & 0.01 & 0.01 & 0.32 \\
\hline Government current disbursements & 0.88 & 0.09 & 0.00 & 0.43 & 0.06 & 0.00 & 0.20 \\
\hline Government current receipts & 0.73 & 0.00 & 0.00 & 0.46 & 0.10 & 0.00 & 0.29 \\
\hline Consumer confidence & 0.47 & 0.51 & 0.12 & 0.89 & 0.24 & 0.01 & 0.61 \\
\hline Business confidence & 0.73 & 0.02 & 0.01 & 0.56 & 0.16 & 0.06 & 0.68 \\
\hline Consumer prices & 0.84 & 0.07 & 0.00 & 0.45 & 0.15 & 0.00 & 0.22 \\
\hline Short-term interest rates & 0.20 & 0.12 & 0.02 & 0.54 & 0.76 & 0.21 & 0.88 \\
\hline Long-term interest rates & 0.31 & 0.12 & 0.02 & 0.47 & 0.84 & 0.19 & 0.88 \\
\hline M1 & n.a. & n.a. & n.a. & n.a. & n.a. & n.a. & n.a. \\
\hline Stock prices & 0.05 & 0.57 & 0.09 & 0.76 & 0.04 & 0.00 & 0.40 \\
\hline Wages & 0.75 & 0.14 & 0.04 & 0.71 & 0.19 & 0.00 & 0.41 \\
\hline Exports total & 0.42 & 0.03 & 0.01 & 0.19 & 0.89 & 0.48 & 0.95 \\
\hline Imports total & 0.37 & 0.12 & 0.01 & 0.28 & 0.46 & 0.24 & 0.86 \\
\hline Terms of trade & 0.42 & 0.29 & 0.02 & 0.60 & 0.69 & 0.03 & 0.66 \\
\hline Real effective exchange & 0.18 & 0.13 & 0.00 & 0.33 & 0.72 & 0.01 & 0.69 \\
\hline Current account balance & 0.03 & 0.64 & 0.27 & 0.86 & 0.26 & 0.01 & 0.53 \\
\hline FDI out & 0.00 & 0.62 & 0.03 & 0.70 & 0.32 & 0.21 & 0.93 \\
\hline FDI in & 0.01 & 0.15 & 0.01 & 0.51 & 0.75 & 0.08 & 0.75 \\
\hline
\end{tabular}

1/ Forecast horizon is 20 quarters and refers to the levels of the series. Confidence intervals are constructed using bootstrapping methods. 
Table 2. Forecast Error Variance of the Common Components of German Variables Explained by the USA Supply Shock and the Demand Shock, 1980-2003 1/

\begin{tabular}{|c|c|c|c|c|c|c|c|}
\hline & \multirow{2}{*}{$\begin{array}{r}\text { Variance Shares } \\
\text { of the Common } \\
\text { Components }\end{array}$} & \multirow{2}{*}{$\begin{array}{l}\text { Supply } \\
\text { Shocks }\end{array}$} & \multicolumn{2}{|c|}{ Confidence Intervals } & \multirow{2}{*}{$\begin{array}{l}\text { Demand } \\
\text { Shocks }\end{array}$} & \multicolumn{2}{|c|}{ Confidence Intervals } \\
\hline & & & Lower Bound & Upper Bound & & Lower Bound & Upper Bound \\
\hline GDP & 0.78 & 0.003 & 0.001 & 0.321 & 0.066 & 0.001 & 0.478 \\
\hline Private investment & 0.57 & 0.039 & 0.002 & 0.422 & 0.110 & 0.001 & 0.598 \\
\hline Personal consumption expenditure & 0.78 & 0.024 & 0.002 & 0.341 & 0.007 & 0.004 & 0.273 \\
\hline Employment & 0.87 & 0.131 & 0.003 & 0.444 & 0.043 & 0.004 & 0.302 \\
\hline Productivity & 0.16 & 0.769 & 0.051 & 0.757 & 0.025 & 0.006 & 0.539 \\
\hline Capacity utilizsation & 0.64 & 0.144 & 0.011 & 0.569 & 0.048 & 0.007 & 0.474 \\
\hline Government current disbursements & 0.83 & 0.193 & 0.004 & 0.524 & 0.009 & 0.019 & 0.392 \\
\hline Government current receipts & 0.76 & 0.082 & 0.003 & 0.371 & 0.030 & 0.005 & 0.283 \\
\hline Consumer confidence & 0.52 & 0.130 & 0.005 & 0.486 & 0.012 & 0.007 & 0.536 \\
\hline Business confidence & 0.62 & 0.057 & 0.005 & 0.440 & 0.146 & 0.035 & 0.636 \\
\hline Consumer prices & 0.56 & 0.361 & 0.003 & 0.498 & 0.201 & 0.001 & 0.224 \\
\hline Short-term interest rates & 0.43 & 0.158 & 0.027 & 0.592 & 0.601 & 0.165 & 0.836 \\
\hline Long-term interest rates & 0.34 & 0.030 & 0.010 & 0.317 & 0.890 & 0.364 & 0.926 \\
\hline M1 & n.a. & n.a. & n.a. & n.a. & n.a. & n.a. & n.a. \\
\hline Stock prices & 0.09 & 0.515 & 0.032 & 0.619 & 0.206 & 0.034 & 0.645 \\
\hline Wages & 0.87 & 0.123 & 0.003 & 0.537 & 0.016 & 0.008 & 0.286 \\
\hline Exports total & 0.34 & 0.164 & 0.007 & 0.221 & 0.487 & 0.283 & 0.910 \\
\hline Imports total & 0.28 & 0.066 & 0.005 & 0.330 & 0.499 & 0.145 & 0.867 \\
\hline Terms of trade & 0.57 & 0.287 & 0.009 & 0.561 & 0.670 & 0.019 & 0.663 \\
\hline Real effective exchange & 0.31 & 0.342 & 0.006 & 0.569 & 0.613 & 0.008 & 0.585 \\
\hline Current account balance & n.a. & n.a. & n.a. & n.a. & n.a. & n.a. & n.a. \\
\hline FDI out & 0.01 & 0.594 & 0.099 & 0.815 & 0.256 & 0.005 & 0.388 \\
\hline FDI in & 0.19 & 0.315 & 0.045 & 0.516 & 0.409 & 0.040 & 0.698 \\
\hline
\end{tabular}

1/ Forecast horizon is 20 quarters and refers to the levels of the series. Confidence intervals are constructed using bootstrapping methods. 
Table 3a. Forecast Error Variance of the Common Components of French Variables Explained by the USA Supply Shock and the Demand Shock, 1991-2003 1/

\begin{tabular}{|c|c|c|c|c|c|c|c|}
\hline & \multirow{2}{*}{$\begin{array}{r}\text { Variance Shares } \\
\text { of the Common } \\
\text { Components }\end{array}$} & \multirow{2}{*}{$\begin{array}{l}\text { Supply } \\
\text { Shocks }\end{array}$} & \multicolumn{2}{|c|}{ Confidence Intervals } & \multirow{2}{*}{$\begin{array}{r}\text { Demand } \\
\text { Shock }\end{array}$} & \multicolumn{2}{|c|}{ Confidence Intervals } \\
\hline & & & Lower Bound & Upper Bound & & Lower Bound & Upper Bound \\
\hline GDP & 0.64 & 0.17 & 0.01 & 0.45 & 0.65 & 0.17 & 0.89 \\
\hline Private investment & 0.72 & 0.36 & 0.01 & 0.46 & 0.37 & 0.15 & 0.88 \\
\hline Personal consumption expenditure & 0.27 & 0.16 & 0.01 & 0.67 & 0.38 & 0.03 & 0.86 \\
\hline Employment & 0.85 & 0.48 & 0.01 & 0.46 & 0.21 & 0.03 & 0.73 \\
\hline Productivity & 0.42 & 0.05 & 0.00 & 0.47 & 0.68 & 0.05 & 0.82 \\
\hline Capacity Utilisation & 0.73 & 0.38 & 0.01 & 0.75 & 0.07 & 0.02 & 0.47 \\
\hline Government current disbursements & 0.63 & 0.53 & 0.01 & 0.68 & 0.20 & 0.06 & 0.88 \\
\hline Government current receipts & 0.20 & 0.42 & 0.01 & 0.53 & 0.46 & 0.17 & 0.88 \\
\hline Consumer confidence & 0.71 & 0.37 & 0.00 & 0.47 & 0.10 & 0.01 & 0.58 \\
\hline Business confidence & 0.74 & 0.38 & 0.01 & 0.39 & 0.29 & 0.04 & 0.76 \\
\hline Consumer prices & 0.32 & 0.35 & 0.00 & 0.62 & 0.07 & 0.01 & 0.65 \\
\hline Short-term interest rates & 0.46 & 0.07 & 0.01 & 0.46 & 0.19 & 0.02 & 0.56 \\
\hline Long-term interest rates & 0.75 & 0.03 & 0.00 & 0.47 & 0.22 & 0.02 & 0.74 \\
\hline M1 & n.a. & n.a. & n.a. & n.a. & n.a. & n.a. & n.a. \\
\hline Stock prices & 0.22 & 0.58 & 0.01 & 0.59 & 0.17 & 0.01 & 0.56 \\
\hline Wages & 0.63 & 0.20 & 0.01 & 0.53 & 0.32 & 0.02 & 0.71 \\
\hline Exports total & 0.50 & 0.16 & 0.01 & 0.37 & 0.47 & 0.10 & 0.78 \\
\hline Imports total & 0.50 & 0.37 & 0.01 & 0.46 & 0.50 & 0.28 & 0.90 \\
\hline Terms of trade & 0.33 & 0.06 & 0.01 & 0.49 & 0.09 & 0.01 & 0.39 \\
\hline Real effective exchange & 0.23 & 0.31 & 0.01 & 0.48 & 0.28 & 0.01 & 0.53 \\
\hline Current account balance & 0.12 & 0.04 & 0.00 & 0.64 & 0.28 & 0.00 & 0.41 \\
\hline FDI out & 0.01 & 0.09 & 0.01 & 0.74 & 0.75 & 0.08 & 0.91 \\
\hline FDI in & 0.02 & 0.07 & 0.00 & 0.49 & 0.06 & 0.01 & 0.36 \\
\hline
\end{tabular}

Table 3b. Forecast Error Variance of the Common Components of German Variables Explained by the USA Supply Shock and the Demand Shock, 1991-2003 1/

\begin{tabular}{|c|c|c|c|c|c|c|c|}
\hline & \multirow{2}{*}{$\begin{array}{r}\text { Variance Shares } \\
\text { of the Common } \\
\text { Components }\end{array}$} & \multirow{2}{*}{$\begin{array}{l}\text { Supply } \\
\text { Shocks }\end{array}$} & \multicolumn{2}{|c|}{ Confidence Intervals } & \multirow{2}{*}{$\begin{array}{r}\text { Demand } \\
\text { Shock }\end{array}$} & \multicolumn{2}{|c|}{ Confidence Intervals } \\
\hline & & & Lower Bound & Upper Bound & & Lower Bound & Upper Bound \\
\hline GDP & 0.42 & 0.15 & 0.01 & 0.60 & 0.81 & 0.22 & 0.97 \\
\hline Private investment & 0.37 & 0.16 & 0.01 & 0.56 & 0.81 & 0.22 & 0.93 \\
\hline Personal consumption expenditure & 0.21 & 0.16 & 0.00 & 0.75 & 0.60 & 0.01 & 0.80 \\
\hline Employment & 0.63 & 0.59 & 0.00 & 0.51 & 0.16 & 0.03 & 0.76 \\
\hline Productivity & 0.42 & 0.12 & 0.01 & 0.61 & 0.80 & 0.05 & 0.83 \\
\hline Capacity utilization & 0.80 & 0.30 & 0.00 & 0.42 & 0.11 & 0.01 & 0.69 \\
\hline Government current disbursements & 0.61 & 0.52 & 0.00 & 0.58 & 0.00 & 0.00 & 0.47 \\
\hline Government current receipts & 0.56 & 0.27 & 0.00 & 0.62 & 0.29 & 0.01 & 0.40 \\
\hline Consumer confidence & 0.64 & 0.19 & 0.01 & 0.59 & 0.31 & 0.02 & 0.69 \\
\hline Business confidence & 0.70 & 0.17 & 0.01 & 0.51 & 0.57 & 0.05 & 0.83 \\
\hline Consumer prices & 0.57 & 0.37 & 0.00 & 0.57 & 0.01 & 0.01 & 0.62 \\
\hline Short-term interest rates & 0.55 & 0.09 & 0.01 & 0.60 & 0.53 & 0.03 & 0.79 \\
\hline Long-term interest rates & 0.37 & 0.02 & 0.00 & 0.47 & 0.21 & 0.01 & 0.74 \\
\hline M1 & n.a. & n.a. & n.a. & n.a. & n.a. & n.a. & n.a. \\
\hline Stock prices & 0.30 & 0.56 & 0.01 & 0.59 & 0.25 & 0.01 & 0.67 \\
\hline Wages & 0.63 & 0.29 & 0.01 & 0.82 & 0.33 & 0.00 & 0.57 \\
\hline Exports total & 0.39 & 0.44 & 0.01 & 0.51 & 0.30 & 0.09 & 0.83 \\
\hline Imports total & 0.39 & 0.45 & 0.01 & 0.54 & 0.46 & 0.22 & 0.91 \\
\hline Terms of trade & 0.24 & 0.14 & 0.01 & 0.46 & 0.19 & 0.02 & 0.63 \\
\hline Real effective exchange & 0.15 & 0.47 & 0.01 & 0.54 & 0.21 & 0.03 & 0.79 \\
\hline Current account balance & n.a. & n.a. & n.a. & n.a. & n.a. & n.a. & n.a. \\
\hline FDI out & 0.01 & 0.22 & 0.01 & 0.65 & 0.06 & 0.02 & 0.40 \\
\hline FDI in & 0.23 & 0.31 & 0.01 & 0.41 & 0.24 & 0.02 & 0.63 \\
\hline
\end{tabular}

1/ Forecast horizon is 20 quarters and refers to the levels of the series. Confidence intervals are constructed using bootstrapping methods. 
Table 4a. Forecast Error Variance of the Common Components of French Variables Explained by the G7 Excluding France Supply Shock and the Demand Shock, 1991-2003 1/

\begin{tabular}{|c|c|c|c|c|c|c|c|}
\hline & \multirow{2}{*}{$\begin{array}{r}\text { Variance Shares } \\
\text { of the Common } \\
\text { Components }\end{array}$} & \multirow{2}{*}{$\begin{array}{l}\text { Supply } \\
\text { Shock }\end{array}$} & \multicolumn{2}{|c|}{ Confidence Intervals } & \multirow{2}{*}{$\begin{array}{r}\text { Demand } \\
\text { Shock }\end{array}$} & \multicolumn{2}{|c|}{ Confidence Intervals } \\
\hline & & & Lower Bound & Upper Bound & & Lower Bound & Upper Bound \\
\hline GDP & 0.64 & 0.11 & 0.01 & 0.35 & 0.81 & 0.41 & 0.96 \\
\hline Private investment & 0.72 & 0.33 & 0.01 & 0.52 & 0.43 & 0.17 & 0.90 \\
\hline Personal consumption expenditure & 0.27 & 0.18 & 0.01 & 0.44 & 0.31 & 0.07 & 0.80 \\
\hline Employment & 0.85 & 0.47 & 0.01 & 0.61 & 0.28 & 0.03 & 0.74 \\
\hline Productivity & 0.42 & 0.15 & 0.01 & 0.41 & 0.79 & 0.16 & 0.91 \\
\hline Capacity utilization & 0.73 & 0.32 & 0.03 & 0.73 & 0.09 & 0.01 & 0.37 \\
\hline Government current disbursements & 0.63 & 0.59 & 0.01 & 0.79 & 0.16 & 0.03 & 0.77 \\
\hline Government current receipts & 0.20 & 0.34 & 0.01 & 0.60 & 0.55 & 0.11 & 0.85 \\
\hline Consumer confidence & 0.71 & 0.38 & 0.01 & 0.54 & 0.18 & 0.01 & 0.60 \\
\hline Business confidence & 0.74 & 0.32 & 0.01 & 0.49 & 0.46 & 0.09 & 0.81 \\
\hline Consumer prices & 0.32 & 0.52 & 0.00 & 0.71 & 0.00 & 0.00 & 0.39 \\
\hline Short-term interest rates & 0.46 & 0.09 & 0.01 & 0.39 & 0.57 & 0.07 & 0.72 \\
\hline Long-term interest rates & 0.75 & 0.09 & 0.00 & 0.39 & 0.58 & 0.19 & 0.89 \\
\hline M1 & n.a. & n.a. & n.a. & n.a. & n.a. & n.a. & n.a. \\
\hline Stock prices & 0.22 & 0.58 & 0.01 & 0.70 & 0.15 & 0.00 & 0.34 \\
\hline Wages & 0.63 & 0.16 & 0.02 & 0.41 & 0.52 & 0.07 & 0.79 \\
\hline Exports total & 0.50 & 0.06 & 0.01 & 0.32 & 0.83 & 0.32 & 0.90 \\
\hline Imports total & 0.50 & 0.27 & 0.01 & 0.55 & 0.69 & 0.35 & 0.95 \\
\hline Terms of trade & 0.33 & 0.02 & 0.00 & 0.38 & 0.43 & 0.01 & 0.55 \\
\hline Real effective exchange & 0.23 & 0.20 & 0.01 & 0.53 & 0.48 & 0.01 & 0.51 \\
\hline Current account balance & 0.12 & 0.08 & 0.00 & 0.53 & 0.03 & 0.00 & 0.43 \\
\hline FDI out & 0.01 & 0.07 & 0.01 & 0.57 & 0.56 & 0.09 & 0.83 \\
\hline FDI in & 0.02 & 0.23 & 0.00 & 0.43 & 0.30 & 0.01 & 0.58 \\
\hline
\end{tabular}

Table 4b. Forecast Error Variance of the Common Components of French Variables Explained by the Euro Area Excluding France Supply Shock and the Demand Shock, 1991-2003 1/

\begin{tabular}{|c|c|c|c|c|c|c|c|}
\hline & \multirow{2}{*}{$\begin{array}{r}\text { Variance Shares } \\
\text { of the Common } \\
\text { Components }\end{array}$} & \multirow{2}{*}{$\begin{array}{r}\text { Supply } \\
\text { Shock }\end{array}$} & \multicolumn{2}{|c|}{ Confidence Intervals } & \multirow{2}{*}{$\begin{array}{r}\text { Demand } \\
\text { Shock }\end{array}$} & \multicolumn{2}{|c|}{ Confidence Intervals } \\
\hline & & & Lower Bound & Upper Bound & & Lower Bound & Upper Bound \\
\hline GDP & 0.64 & 0.77 & 0.09 & 0.91 & 0.21 & 0.05 & 0.88 \\
\hline Private investment & 0.72 & 0.80 & 0.12 & 0.92 & 0.04 & 0.02 & 0.74 \\
\hline Personal consumption expenditure & 0.27 & 0.53 & 0.01 & 0.78 & 0.07 & 0.03 & 0.82 \\
\hline Employment & 0.85 & 0.80 & 0.07 & 0.88 & 0.04 & 0.01 & 0.62 \\
\hline Productivity & 0.42 & 0.20 & 0.00 & 0.48 & 0.65 & 0.12 & 0.91 \\
\hline Capacity utilization & 0.73 & 0.26 & 0.05 & 0.50 & 0.15 & 0.01 & 0.52 \\
\hline Government current disbursements & 0.63 & 0.67 & 0.15 & 0.93 & 0.10 & 0.01 & 0.52 \\
\hline Government current receipts & 0.20 & 0.93 & 0.08 & 0.91 & 0.03 & 0.02 & 0.74 \\
\hline Consumer confidence & 0.71 & 0.61 & 0.04 & 0.78 & 0.04 & 0.01 & 0.58 \\
\hline Business confidence & 0.74 & 0.84 & 0.08 & 0.88 & 0.04 & 0.02 & 0.72 \\
\hline Consumer prices & 0.32 & 0.30 & 0.01 & 0.75 & 0.19 & 0.00 & 0.39 \\
\hline Short-term interest rates & 0.46 & 0.32 & 0.02 & 0.64 & 0.32 & 0.03 & 0.69 \\
\hline Long-term interest rates & 0.75 & 0.17 & 0.01 & 0.72 & 0.34 & 0.01 & 0.65 \\
\hline M1 & n.a. & n.a. & n.a. & n.a. & n.a. & n.a. & n.a. \\
\hline Stock prices & 0.22 & 0.67 & 0.01 & 0.70 & 0.09 & 0.00 & 0.36 \\
\hline Wages & 0.63 & 0.66 & 0.03 & 0.76 & 0.14 & 0.03 & 0.80 \\
\hline Exports total & 0.50 & 0.66 & 0.05 & 0.77 & 0.19 & 0.04 & 0.77 \\
\hline Imports total & 0.50 & 0.93 & 0.25 & 0.95 & 0.06 & 0.02 & 0.73 \\
\hline Terms of trade & 0.33 & 0.24 & 0.01 & 0.56 & 0.14 & 0.01 & 0.45 \\
\hline Real effective exchange & 0.23 & 0.74 & 0.01 & 0.71 & 0.03 & 0.01 & 0.56 \\
\hline Current account balance & 0.12 & 0.11 & 0.01 & 0.59 & 0.00 & 0.00 & 0.36 \\
\hline FDI out & 0.01 & 0.41 & 0.02 & 0.65 & 0.13 & 0.03 & 0.62 \\
\hline FDI in & 0.02 & 0.03 & 0.01 & 0.42 & 0.38 & 0.01 & 0.59 \\
\hline
\end{tabular}

1/ Forecast horizon is 20 quarters and refers to the levels of the series. Confidence intervals are constructed using bootstrapping methods. 
APPENDIX I. Macroeconomic Series

\begin{tabular}{|c|c|c|c|c|c|}
\hline Number & r Country & Variable Name & Unit Root & $\log$ & Treatment \\
\hline 1 & France & Balance of income, value, balance of payments basis & 1 & $\mathrm{nl}$ & 2 \\
\hline 2 & France & Current account, value & 1 & $\mathrm{nl}$ & 2 \\
\hline 3 & France & Government consumption of fixed capital, value & 1 & 1 & 3 \\
\hline 4 & France & Private final consumption expenditure, volume \euros 1995 & 1 & 1 & 3 \\
\hline 5 & France & Dependent employment $\backslash$ persons & 1 & 1 & 3 \\
\hline 6 & France & Dependent employment of the business sector $\backslash$ persons & 1 & 1 & 3 \\
\hline 7 & France & Government employment $\backslash$ persons & 1 & 1 & 3 \\
\hline 8 & France & Self-employed $\backslash$ persons & 1 & 1 & 3 \\
\hline 9 & France & Total employment $\backslash$ persons & 1 & 1 & 3 \\
\hline 10 & France & Exchange rate, index of US\$ per local currency $\backslash$ index & 1 & 1 & 3 \\
\hline 11 & France & Employment of the business sector $\backslash$ persons & 1 & 1 & 3 \\
\hline 12 & France & Real Effective exchange rate, $2000=100$, ULC-based & 1 & 1 & 3 \\
\hline 13 & France & Gross domestic product, volume, market prices \euros 1995 & 1 & 1 & 3 \\
\hline 14 & France & Private nonresidential fixed capital formation, volume $\backslash$ euros 1995 & 1 & 1 & 3 \\
\hline 15 & France & Fixed investment in nonresidential construction, volume & 1 & 1 & 3 \\
\hline 16 & France & Government fixed capital formation, volume $\backslash$ euros 1995 & 1 & 1 & 3 \\
\hline 17 & France & Private residential fixed capital formation, volume $\backslash$ euros 1995 & 1 & 1 & 3 \\
\hline 18 & France & Fixed investment in machinery and equipment, volume $\backslash$ euros & 1 & 1 & 3 \\
\hline 19 & France & Industrial production $\backslash$ index 1995 & 1 & 1 & 3 \\
\hline 20 & France & Private total fixed capital formation, volume $\backslash$ euros 1995 & 1 & 1 & 3 \\
\hline 21 & France & Long-term interest rate on government bonds $\backslash$ percent & 1 & $\mathrm{nl}$ & 2 \\
\hline 22 & France & Gross total fixed capital formation, volume $\backslash$ euros 1995 & 1 & 1 & 3 \\
\hline 23 & France & Labor force $\backslash$ persons & 1 & 1 & 3 \\
\hline 24 & France & Labor force participation rate & 1 & 1 & 3 \\
\hline 25 & France & Imports of goods and services, volume, national accounts basis $\backslash$ euros & 1 & 1 & 3 \\
\hline 26 & France & Factor income paid abroad, volume, balance of payments basis $\backslash$ local currency & 1 & 1 & 3 \\
\hline 27 & France & Labor productivity of the total economy $\backslash$ index 2000 & 1 & 1 & 3 \\
\hline 28 & France & Labor productivity of the business economy $\backslash$ euros & 1 & 1 & 3 \\
\hline 29 & France & Government saving (net), value $\backslash$ euros & 1 & $\mathrm{nl}$ & 2 \\
\hline 30 & France & Household saving ratio $\backslash$ percent & 1 & $\mathrm{nl}$ & 2 \\
\hline 31 & France & Current transfers received by households, value $\backslash$ euros & 1 & 1 & 3 \\
\hline 32 & France & Unit labor cost of the total economy $\backslash$ index 2000 & 1 & 1 & 3 \\
\hline 33 & France & Unit labor cost of the manufacturing sector $\backslash$ index 1995 & 1 & 1 & 3 \\
\hline 34 & France & Unemployment $\backslash$ persons & 1 & 1 & 3 \\
\hline 35 & France & Unemployment rate $\backslash$ percent & 1 & $\mathrm{nl}$ & 2 \\
\hline 36 & France & Wages, value $\backslash$ euros & 1 & 1 & 3 \\
\hline 37 & France & Wages of the government sector, value $\backslash$ euros & 1 & 1 & 3 \\
\hline 38 & France & Compensation rate of government employees $\backslash$ euros & 1 & 1 & 3 \\
\hline 39 & France & Wage rate of the manufacturing sector, hourly earnings $\backslash$ index 1995 & 1 & $\mathrm{nl}$ & 2 \\
\hline 40 & France & Compensation rate of the business sector $\backslash$ yearly salary in euro & 1 & 1 & 3 \\
\hline 41 & France & Compensation of employees, value $\backslash$ euros & 1 & 1 & 3 \\
\hline 42 & France & Exports of goods and services, volume, national accounts basis $\backslash$ euros 1995 & 1 & 1 & 3 \\
\hline 43 & France & Factor income from abroad, volume, balance of payments basis $\backslash$ local currency & 1 & 1 & 3 \\
\hline 44 & France & Property income received by households, value $\backslash$ euros & 1 & 1 & 3 \\
\hline 45 & France & Government current disbursements, value $\backslash$ euros & 1 & 1 & 3 \\
\hline 46 & France & Current disbursements of households, value $\backslash$ euros & 1 & 1 & 3 \\
\hline 47 & France & Government current receipts, value $\backslash$ euros & 1 & 1 & 3 \\
\hline 48 & France & Current receipts of households, value $\backslash$ euros & 1 & 1 & 3 \\
\hline 49 & France & Self-employment income received by households, value $\backslash$ euros & 1 & 1 & 3 \\
\hline 50 & France & Direct Investment abroad & 1 & $\mathrm{nl}$ & 2 \\
\hline 51 & France & Dir. invest. in rep. econ., N.I.E. & 1 & $\mathrm{nl}$ & 2 \\
\hline 52 & France & Portfolio investment liab., N.I.E. & 1 & $\mathrm{nl}$ & 2 \\
\hline 53 & France & Exports prices & 1 & 1 & 3 \\
\hline 54 & France & Imports prices & 1 & 1 & 3 \\
\hline 55 & France & Terms of trade & 1 & 1 & 3 \\
\hline 56 & France & CPI: 108 cities (index number, 2000=100, AQM, DEC, average) & 1 & 1 & 3 \\
\hline 57 & France & Francelinterest rates\confidence and economic sentiment lshare prices SBF 250 / stock & 1 & 1 & 3 \\
\hline 58 & France & Treasury bills: 3 months (percent per annum, AQM, DEC, average) & 1 & $\mathrm{nl}$ & 2 \\
\hline 59 & France & Cyclical indicators/surveys of manufacturing industry:lindustrial confidence indicator & 0 & $\mathrm{nl}$ & 0 \\
\hline 60 & France & ICyclical indicators \consumer opinion on economic and financial & 0 & $\mathrm{nl}$ & 0 \\
\hline 61 & France & Fixed investment in construction, volume & 0 & 1 & 1 \\
\hline 62 & France & Increase in stocks, volume $\backslash$ euros 1995 & 0 & $\mathrm{nl}$ & 0 \\
\hline 63 & France & Wage rate of the business sector $\backslash$ euros per & 0 & 1 & 1 \\
\hline 64 & France & Household disposable income, real $\backslash$ euros & 0 & 1 & 1 \\
\hline 65 & France & Francelcyclical indicators\surveys of manufacturing industry:|current level of capacity & 0 & 1 & 1 \\
\hline 66 & France & Portfolio investment assets & 0 & $\mathrm{nl}$ & 0 \\
\hline 67 & France & Other investment assets & 0 & $\mathrm{nl}$ & 0 \\
\hline 68 & France & Other investment liab., N.I.E. & 0 & $\mathrm{nl}$ & 0 \\
\hline 69 & France & Financial account, N.I.E. & 0 & $\mathrm{nl}$ & 0 \\
\hline 70 & Germany & Government consumption of fixed capital, value $\backslash$ euros & 1 & 1 & 3 \\
\hline 71 & Germany & Private final consumption expenditure, volume $\backslash$ euros 1995 & 1 & 1 & 3 \\
\hline 72 & Germany & Dependent employment $\backslash$ persons & 1 & 1 & 3 \\
\hline 73 & Germany & Dependent employment of the business sector & 1 & 1 & 3 \\
\hline 74 & Germany & Government employment $\backslash$ persons & 1 & 1 & 3 \\
\hline 75 & Germany & Self-employed $\backslash$ persons & 1 & 1 & 3 \\
\hline 76 & Germany & Total employment $\backslash$ persons & 1 & 1 & 3 \\
\hline 77 & Germany & Employment of the business sector & 1 & 1 & 3 \\
\hline 78 & Germany & Exchange rate, index of US\$ per local currency $\backslash$ index & 1 & 1 & 3 \\
\hline 79 & Germany & Real Effective exchange rate, $2000=100$, ULC-based & 1 & 1 & 3 \\
\hline 80 & Germany & Gross domestic product, volume, market prices \euros 1995 & 1 & 1 & 3 \\
\hline 81 & Germany & Private nonresidential fixed capital formation, volume $\backslash$ euros 1995 & 1 & 1 & 3 \\
\hline
\end{tabular}


APPENDIX I. Macroeconomic Series (continued)

\begin{tabular}{|c|c|c|c|c|c|}
\hline Number & Country & Variable Name & Unit Root & $\log$ & Treatment \\
\hline 82 & Germany & Fixed investment in nonresidential construction, volume & 1 & 1 & 3 \\
\hline 83 & Germany & Fixed investment in construction, volume $\backslash \mathrm{DM}$ & 1 & 1 & 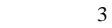 \\
\hline 84 & Germany & Government fixed capital formation, volume \euros 1995 & 1 & 1 & 3 \\
\hline 85 & Germany & Private residential fixed capital formation, volume $\backslash$ euros 1995 & 1 & 1 & 3 \\
\hline 86 & Germany & Fixed investment in machinery and equipment, volume $\backslash \mathrm{DM}$ & 1 & 1 & 3 \\
\hline 87 & Germany & Industrial production & 1 & 1 & 3 \\
\hline 88 & Germany & Private total fixed capital formation, volume $\backslash$ euros 1995 & 1 & 1 & 3 \\
\hline 89 & Germany & Long-term interest rate on government bonds $\backslash$ percent & 1 & $\mathrm{nl}$ & 7 \\
\hline 90 & Germany & Gross total fixed capital formation, volume $\backslash$ euros 1995 & 1 & l & 3 \\
\hline 91 & Germany & Labor force & 1 & 1 & 3 \\
\hline 92 & Germany & Imports of goods and services, volume, national accounts basis $\backslash$ euros 1995 & 1 & 1 & 3 \\
\hline 93 & Germany & Labor productivity of the total economy $\backslash$ index 2000 & 1 & 1 & 3 \\
\hline 94 & Germany & Labor productivity of the business economy & 1 & 1 & 3 \\
\hline 95 & Germany & Government saving (net), value $\backslash$ euros & 1 & $\mathrm{nl}$ & 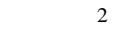 \\
\hline 96 & Germany & Current transfers received by households, value & 1 & l & 3 \\
\hline 97 & Germany & Unit labor cost of the total economy & 1 & 1 & 3 \\
\hline 98 & Germany & Unit labor cost of the manufacturing sector $\backslash$ Local currency index & 1 & 1 & 3 \\
\hline 99 & Germany & Unemployment $\backslash$ euros & 1 & 1 & 3 \\
\hline 100 & Germany & Unemployment rate $\backslash$ percent & 1 & $\mathrm{nl}$ & 2 \\
\hline 101 & Germany & Wages, value $\backslash$ euros & 1 & 1 & 3 \\
\hline 102 & Germany & Wage rate of the business sector & 1 & 1 & 7 \\
\hline 103 & Germany & Compensation rate of government employees & 1 & l & 3 \\
\hline 104 & Germany & Compensation rate of the business sector $\backslash \mathrm{DM}$ & 1 & 1 & 3 \\
\hline 105 & Germany & Compensation of employees, value $\backslash$ euros & 1 & 1 & 3 \\
\hline 106 & Germany & Exports of goods and services, volume, national accounts basis $\backslash$ euros 1995 & 1 & 1 & 3 \\
\hline 107 & Germany & Household disposable income, real $\backslash$ euros & 1 & 1 & 3 \\
\hline 108 & Germany & Government current disbursements, value $\backslash$ euros & 1 & $\mathrm{l}$ & 3 \\
\hline 109 & Germany & Current disbursements of households, value $\backslash$ euros & 1 & 1 & 3 \\
\hline 110 & Germany & Government current receipts, value $\backslash$ euros & 1 & 1 & 3 \\
\hline 111 & Germany & Current receipts of households, value $\backslash$ euros & 1 & 1 & 3 \\
\hline 112 & Germany & Direct Investment abroad & 1 & $\mathrm{nl}$ & 2 \\
\hline 113 & Germany & Portfolio investment assets & 1 & $\mathrm{nl}$ & 2 \\
\hline 114 & Germany & Portfolio investment liab., N.I.E. & 1 & $\mathrm{nl}$ & ? \\
\hline 115 & Germany & Exports prices & 1 & l & 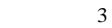 \\
\hline 116 & Germany & Imports prices & 1 & 1 & 3 \\
\hline 117 & Germany & Terms of trade & 1 & 1 & 3 \\
\hline 118 & Germany & Share prices (Index number, AQM, DEC, average) & 1 & l & 3 \\
\hline 119 & Germany & Call money rate (percent per annum, AQM, DEC, average) & 1 & $\mathrm{nl}$ & 2 \\
\hline 120 & Germany & Consumer Price Index (SA, 2000=100) & 1 & 1 & 3 \\
\hline 121 & Germany & PPI: total manufacturing industries $(\mathrm{SA}, 2000=100)$ & 1 & 1 & 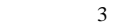 \\
\hline 122 & Germany & Cyclical indicators \surveys of manufacturing industry:lindustrial confidence indicator & 0 & $\mathrm{nl}$ & 0 \\
\hline 123 & Germany & Cyclical indicators lconsumer opinion on economic and financial & 0 & $\mathrm{nl}$ & 0 \\
\hline 124 & Germany & Increase in stocks, volume $\backslash$ euros 1995 & 0 & $\mathrm{nl}$ & 0 \\
\hline 125 & Germany & Household saving ratio $\backslash$ percent & 0 & $\mathrm{nl}$ & 0 \\
\hline 126 & Germany & The Federal Republic of Germany (prior to 1990Q4 West-Germany) \cyclical & 0 & 1 & 1 \\
\hline 127 & Germany & Dir. Invest. in Rep. Econ., N.I.E. & 0 & $\mathrm{nl}$ & 0 \\
\hline 128 & Germany & Other investment assets & 0 & $\mathrm{nl}$ & . \\
\hline 129 & Germany & Other investment liab., N.I.E. & 0 & $\mathrm{nl}$ & 0 \\
\hline 130 & Germany & Financial account, N.I.E. & 0 & $\mathrm{nl}$ & 0 \\
\hline 131 & Italy & Balance of income, value, balance of payments basis & 1 & $\mathrm{nl}$ & 2 \\
\hline 132 & Italy & Current account, value & 1 & $\mathrm{nl}$ & 2 \\
\hline 133 & Italy & Government consumption of fixed capital, value $\backslash$ euros & 1 & 1 & 3 \\
\hline 134 & Italy & Private final consumption expenditure, volume $\backslash$ euros 1995 & 1 & 1 & 3 \\
\hline 135 & Italy & Dependent employment $\backslash$ persons & 1 & 1 & 3 \\
\hline 136 & Italy & Self-employed $\backslash$ persons & 1 & 1 & 3 \\
\hline 137 & Italy & Total employment $\backslash$ persons & 1 & l & 3 \\
\hline 138 & Italy & Employment of the business sector $\backslash$ persons & 1 & 1 & $\sigma$ \\
\hline 139 & Italy & Exchange rate, index of US\$ per local currency $\backslash$ index & 1 & 1 & 3 \\
\hline 140 & Italy & Private non-residential fixed capital formation, volume $\backslash$ euros & 1 & 1 & 3 \\
\hline 141 & Italy & Fixed investment in non-residential construction, volume $\backslash$ euros & 1 & 1 & 3 \\
\hline 142 & Italy & Fixed investment in construction, volume $\backslash$ euros & 1 & 1 & 3 \\
\hline 143 & Italy & Government fixed capital formation, volume $\backslash$ euros & 1 & 1 & 3 \\
\hline 144 & Italy & Private residential fixed capital formation, volume $\backslash$ euros & 1 & 1 & 3 \\
\hline 145 & Italy & Fixed investment in machinery and equipment, volume $\backslash$ euros & 1 & 1 & 3 \\
\hline 146 & Italy & Industrial production $\backslash$ index 1995 & 1 & 1 & 3 \\
\hline 147 & Italy & Private total fixed capital formation, volume $\backslash$ euros & 1 & 1 & 3 \\
\hline 148 & Italy & Long-term interest rate on government bonds $\backslash$ percent & 1 & $\mathrm{nl}$ & 2 \\
\hline 149 & Italy & Gross total fixed capital formation, volume $\backslash$ euros & 1 & 1 & 3 \\
\hline 150 & Italy & Capital stock of the business sector, volume $\backslash$ euros & 1 & 1 & 3 \\
\hline 151 & Italy & Capital stock, housing, volume & 1 & 1 & 3 \\
\hline 152 & Italy & Labor force $\backslash$ persons & 1 & l & 3 \\
\hline 153 & Italy & Labor force participation rate & 1 & $\mathrm{nl}$ & 2 \\
\hline 154 & Italy & Imports of goods and services, volume, national accounts basis $\backslash$ euros & 1 & 1 & 3 \\
\hline 155 & Italy & Factor income paid abroad, volume, balance of payments basis $\backslash$ local currency & 1 & 1 & 3 \\
\hline 156 & Italy & Labor productivity of the total economy $\backslash$ index 2000 & 1 & 1 & 3 \\
\hline 157 & Italy & Labor productivity of the business economy $\backslash$ euros & 1 & 1 & J \\
\hline 158 & Italy & Government saving (net), value $\backslash$ euros & 1 & $\mathrm{nl}$ & 2 \\
\hline 159 & Italy & Household saving, value $\backslash$ euros & 1 & 1 & 3 \\
\hline 160 & Italy & Household saving ratio $\backslash$ percent & 1 & $\mathrm{nl}$ & 2 \\
\hline 161 & Italy & Current transfers received by households, value $\backslash$ euros & 1 & 1 & 3 \\
\hline 162 & Italy & Unit labor cost of the total economy $\backslash$ local currency & 1 & 1 & 3 \\
\hline
\end{tabular}


APPENDIX I. Macroeconomic Series (continued)

\begin{tabular}{|c|c|c|c|c|c|}
\hline Number & Country & Variable Name & Unit Root & $\log$ & Treatment \\
\hline 163 & Italy & Unit labor cost of the manufacturing sector $\backslash$ local currency index & 1 & 1 & 3 \\
\hline 164 & Italy & Unemployment $\backslash$ persons & 1 & 1 & 3 \\
\hline 165 & Italy & Unemployment rate $\backslash$ percent & 1 & $\mathrm{nl}$ & 2 \\
\hline 166 & Italy & Wages, value $\backslash$ euros & 1 & 1 & 3 \\
\hline 167 & Italy & Wage rate of the business sector $\backslash$ euros/person & 1 & 1 & 3 \\
\hline 168 & Italy & Compensation rate of government employees $\backslash$ euros/person & 1 & 1 & 3 \\
\hline 169 & Italy & Wage rate of the manufacturing sector, hourly earnings $\backslash$ index 1995 & 1 & 1 & 3 \\
\hline 170 & Italy & Compensation rate of the business sector $\backslash$ yearly salary in euros per & 1 & 1 & 3 \\
\hline 171 & Italy & Compensation of employees, value $\backslash$ euros & 1 & 1 & 3 \\
\hline 172 & Italy & Exports of goods and services, volume, national accounts basis $\backslash$ euros & 1 & 1 & 3 \\
\hline 173 & Italy & Factor income from abroad, volume, balance of payments basis $\backslash$ local currency & 1 & 1 & 3 \\
\hline 174 & Italy & Household disposable income, real $\backslash$ euros & 1 & 1 & 3 \\
\hline 175 & Italy & Property income received by households, value $\backslash$ euros & 1 & 1 & 3 \\
\hline 176 & Italy & Government current disbursements, value $\backslash$ euros & 1 & 1 & 3 \\
\hline 177 & Italy & Current disbursements of households, value $\backslash$ euros & 1 & 1 & 3 \\
\hline 178 & Italy & Government current receipts, value $\backslash$ euros & 1 & l & 3 \\
\hline 179 & Italy & Current receipts of households, value $\backslash$ euros & 1 & 1 & 3 \\
\hline 180 & Italy & Self-employment income received by households, value $\backslash$ euros & 1 & 1 & 3 \\
\hline 181 & Italy & Portfolio investment liab., N.I.E. & 1 & $\mathrm{nl}$ & 2 \\
\hline 182 & Italy & Exports prices & 1 & 1 & 3 \\
\hline 183 & Italy & Imports prices & 1 & 1 & 3 \\
\hline 184 & Italy & Terms of trade & 1 & 1 & 3 \\
\hline 185 & Italy & CPI: all Italy (index number, $2000=100, A Q M$, DEC, average) & 1 & 1 & 3 \\
\hline 186 & Italy & Italylinterest rates\confidence and economic sentiment \share prices ISE MIB & 1 & 1 & 3 \\
\hline 187 & Italy & Money market rate (percent per annum, AQM, DEC, average) & 1 & $\mathrm{nl}$ & 2 \\
\hline 188 & Italy & Real Effective exchange rate, $2000=100$, ULC-based & 0 & 1 & 1 \\
\hline 189 & Italy & Gross domestic product, volume, market prices $\backslash$ EUROS 1995 & 0 & 1 & 1 \\
\hline 190 & Italy & Increase in stocks, volume $\backslash$ EUROS & 0 & $\mathrm{nl}$ & 0 \\
\hline 191 & Italy & Italy/cyclical indicators/surveys of manufacturing industry:/current level of capacity & 0 & 1 & 1 \\
\hline 192 & Italy & Direct investment abroad & 0 & $\mathrm{nl}$ & 0 \\
\hline 193 & Italy & Dir. invest. in rep. econ., N.I.E. & 0 & $\mathrm{nl}$ & 0 \\
\hline 194 & Italy & Portfolio investment assets & 0 & $\mathrm{nl}$ & 0 \\
\hline 195 & Italy & Other investment assets & 0 & $\mathrm{nl}$ & 0 \\
\hline 196 & Italy & Other investment liab., N.I.E. & 0 & $\mathrm{nl}$ & 0 \\
\hline 197 & Italy & Financial account, N.I.E. & 0 & $\mathrm{nl}$ & 0 \\
\hline 198 & Japan & Balance of income, value, balance of payments basis & 1 & $\mathrm{nl}$ & 2 \\
\hline 199 & Japan & Current account, value & 1 & $\mathrm{nl}$ & 2 \\
\hline 200 & Japan & Government consumption of fixed capital, value $\backslash$ JPY & 1 & 1 & 3 \\
\hline 201 & Japan & Private final consumption expenditure, volume $\backslash$ JPY 2000 & 1 & 1 & 3 \\
\hline 202 & Japan & Dependent employment $\backslash$ persons & 1 & 1 & 3 \\
\hline 203 & Japan & Dependent employment of the business sector $\backslash$ persons & 1 & 1 & 3 \\
\hline 204 & Japan & Government employment $\backslash$ persons & 1 & 1 & 3 \\
\hline 205 & Japan & Self-employed $\backslash$ persons & 1 & 1 & 3 \\
\hline 206 & Japan & Total employment $\backslash$ persons & 1 & 1 & 3 \\
\hline 207 & Japan & Employment of the business sector $\backslash$ persons & 1 & 1 & 3 \\
\hline 208 & Japan & Exchange rate, index of US\$ per local currency $\backslash$ index & 1 & 1 & 3 \\
\hline 209 & Japan & Real Effective exchange rate, $2000=100$, ULC-based & 1 & 1 & 3 \\
\hline 210 & Japan & Gross domestic product, volume, market prices $\backslash$ JPY 2000 & 1 & 1 & 3 \\
\hline 211 & Japan & Private non-residential fixed capital formation, volume $\backslash$ JPY 2000 & 1 & 1 & 3 \\
\hline 212 & Japan & Fixed investment of government enterprises, volume $\backslash$ JPY 2000 & 1 & 1 & 3 \\
\hline 213 & Japan & Government fixed capital formation, volume $\backslash$ JPY 2000 & 1 & 1 & 3 \\
\hline 214 & Japan & Private residential fixed capital formation, volume $\backslash$ JPY 2000 & 1 & 1 & 3 \\
\hline 215 & Japan & Industrial production $\backslash$ index 2000 & 1 & 1 & 3 \\
\hline 216 & Japan & Private total fixed capital formation, volume $\backslash$ JPY 2000 & 1 & 1 & 3 \\
\hline 217 & Japan & Long-term interest rate on government bonds $\backslash$ percent & 1 & $\mathrm{nl}$ & 2 \\
\hline 218 & Japan & Gross total fixed capital formation, volume $\backslash$ JPY 2000 & 1 & 1 & 3 \\
\hline 219 & Japan & Capital stock of the business sector, volume $\backslash$ JPY 2000 & 1 & 1 & 3 \\
\hline 220 & Japan & Capital stock, housing, volume $\backslash$ JPY 2000 & 1 & 1 & 3 \\
\hline 221 & Japan & Labor force $\backslash$ persons & 1 & 1 & 3 \\
\hline 222 & Japan & Labor force participation rate & 1 & $\mathrm{nl}$ & 2 \\
\hline 223 & Japan & Imports of goods and services, volume, national accounts basis $\backslash$ JPY 2000 & 1 & 1 & 3 \\
\hline 224 & Japan & Money supply, broad definition: M2 or M3 $\backslash$ JPY & 1 & 1 & 3 \\
\hline 225 & Japan & Factor income paid abroad, volume, balance of payments basis $\backslash$ local currency & 1 & 1 & 3 \\
\hline 226 & Japan & Labor productivity of the total economy $\backslash$ index 2000 & 1 & 1 & 3 \\
\hline 227 & Japan & Labor productivity of the business economy & 1 & 1 & 3 \\
\hline 228 & Japan & Government saving (net), value $\backslash J P Y$ & 1 & $\mathrm{nl}$ & 2 \\
\hline 229 & Japan & Household saving, value $\backslash$ JPY & 1 & 1 & 3 \\
\hline 230 & Japan & Household saving ratio $\backslash$ percent & 1 & $\mathrm{nl}$ & 2 \\
\hline 231 & Japan & Unit labor cost of the total economy $\backslash$ index 2000 & 1 & 1 & 3 \\
\hline 232 & Japan & Unit labor cost of the manufacturing sector $\backslash$ index 2000 & 1 & 1 & 3 \\
\hline 233 & Japan & Unemployment $\backslash$ persons & 1 & 1 & 3 \\
\hline 234 & Japan & Unemployment rate $\backslash$ percent & 1 & $\mathrm{nl}$ & 2 \\
\hline 235 & Japan & Velocity of money & 1 & 1 & 3 \\
\hline 236 & Japan & Wages, value $\backslash$ JPY & 1 & 1 & 3 \\
\hline 237 & Japan & Wage rate of the business sector $\backslash$ index & 1 & 1 & 3 \\
\hline 238 & Japan & Compensation rate of government employees & 1 & 1 & 3 \\
\hline 239 & Japan & Wage rate of the manufacturing sector, hourly earnings $\backslash$ index 2000 & 1 & 1 & 3 \\
\hline 240 & Japan & Compensation rate of the business sector $\backslash$ yearly salary in yen per & 1 & 1 & 3 \\
\hline 241 & Japan & Compensation of employees, value $\backslash J P Y$ & 1 & 1 & 3 \\
\hline 242 & Japan & Exports of goods and services, volume, national accounts basis $\backslash$ JPY 2000 & 1 & 1 & 3 \\
\hline 243 & Japan & Factor income from abroad, volume, balance of payments basis $\backslash$ local currency & 1 & 1 & 3 \\
\hline
\end{tabular}


APPENDIX I. Macroeconomic Series (continued)

\begin{tabular}{|c|c|c|c|c|c|}
\hline Number & Country & Variable Name & Unit Root & $\log$ & Treatment \\
\hline 244 & Japan & Household disposable income, real $\backslash$ JPY & 1 & 1 & 3 \\
\hline 245 & Japan & Property income received by households, value $\backslash \mathrm{JPY}$ & 1 & 1 & 3 \\
\hline 246 & Japan & Government current disbursements, value $\backslash J P Y$ & 1 & l & 3 \\
\hline 247 & Japan & Current disbursements of households, value $\backslash$ JPY & 1 & 1 & 3 \\
\hline 248 & Japan & Government current receipts, value $\backslash$ JPY & 1 & 1 & 3 \\
\hline 249 & Japan & Current receipts of households, value $\backslash \mathrm{JPY}$ & 1 & 1 & 3 \\
\hline 250 & Japan & Self-employment income received by households, value $\backslash \mathrm{JPY}$ & 1 & 1 & 3 \\
\hline 251 & Japan & Direct Investment abroad & 1 & $\mathrm{nl}$ & 2 \\
\hline 252 & Japan & Portfolio investment assets & 1 & $\mathrm{nl}$ & 2 \\
\hline 253 & Japan & Financial account, N.I.E. & 1 & $\mathrm{nl}$ & 2 \\
\hline 254 & Japan & Exports prices & 1 & 1 & 3 \\
\hline 255 & Japan & Imports prices & 1 & 1 & 3 \\
\hline 256 & Japan & Terms of trade & 1 & 1 & 3 \\
\hline 257 & Japan & Call monetary rate (percent per annum, AQM, DEC, average) & 1 & $\mathrm{nl}$ & 2 \\
\hline 258 & Japan & Share prices (index number, AQM, DEC, average) & 1 & 1 & 3 \\
\hline 259 & Japan & PPI / WPI (Index number, 2000=100, AQM, DEC, average) & 1 & 1 & 3 \\
\hline 260 & Japan & CPI: all Japan-485 items (Index number, 2000=100, AQM, DEC, average) & 1 & 1 & 3 \\
\hline 261 & Japan & Increase in stocks, volume $\backslash$ JPY 2000 & 0 & $\mathrm{nl}$ & 0 \\
\hline 262 & Japan & Current transfers received by households, value $\backslash \mathrm{JPY}$ & 0 & 1 & 1 \\
\hline 263 & Japan & Dir. invest. in rep. econ., N.I.E. & 0 & $\mathrm{nl}$ & 0 \\
\hline 264 & Japan & Portfolio investment liab., N.I.E. & 0 & $\mathrm{nl}$ & 0 \\
\hline 265 & Japan & Other investment liab., N.I.E. & 0 & $\mathrm{nl}$ & 0 \\
\hline 266 & Spain & Balance of income, value, balance of payments basis & 1 & $\mathrm{nl}$ & 2 \\
\hline 267 & Spain & Current account, value & 1 & $\mathrm{nl}$ & 2 \\
\hline 268 & Spain & Government consumption of fixed capital, value $\backslash$ euros & 1 & 1 & 3 \\
\hline 269 & Spain & Unit capital-labor costs & 1 & 1 & 3 \\
\hline 270 & Spain & Private final consumption expenditure, volume $\backslash$ euros & 1 & 1 & 3 \\
\hline 271 & Spain & Dependent employment $\backslash$ persons & 1 & 1 & 3 \\
\hline 272 & Spain & Dependent employment of the business sector $\backslash$ persons & 1 & 1 & 3 \\
\hline 273 & Spain & Government employment $\backslash$ persons & 1 & 1 & 3 \\
\hline 274 & Spain & Self-employed $\backslash$ persons & 1 & 1 & 3 \\
\hline 275 & Spain & Total employment $\backslash$ persons & 1 & 1 & 3 \\
\hline 276 & Spain & Employment of the business sector $\backslash$ persons & 1 & 1 & 3 \\
\hline 277 & Spain & Exchange rate, index of US\$ per local currency $\backslash$ index & 1 & 1 & 3 \\
\hline 278 & Spain & Real Effective exchange rate, $2000=100$, ULC-based & 1 & 1 & 3 \\
\hline 279 & Spain & Gross domestic product, volume, market prices $\backslash$ euros & 1 & l & 3 \\
\hline 280 & Spain & Private non-residential fixed capital formation, volume $\backslash$ euros & 1 & 1 & 3 \\
\hline 281 & Spain & Fixed investment in non-residential construction, volume $\backslash$ euros & 1 & 1 & 3 \\
\hline 282 & Spain & Fixed investment in construction, volume & 1 & 1 & 3 \\
\hline 283 & Spain & Government fixed capital formation, volume $\backslash$ euros & 1 & 1 & 3 \\
\hline 284 & Spain & Private residential fixed capital formation, volume $\backslash$ euros & 1 & l & 3 \\
\hline 285 & Spain & Fixed investment in machinery and equipment, volume $\backslash$ euros & 1 & 1 & 3 \\
\hline 286 & Spain & Industrial production $\backslash$ index & 1 & 1 & 3 \\
\hline 287 & Spain & Private total fixed capital formation, volume $\backslash$ euros & 1 & 1 & 3 \\
\hline 288 & Spain & Long-term interest rate on government bonds $\backslash$ percent & 1 & $\mathrm{nl}$ & 2 \\
\hline 289 & Spain & Gross total fixed capital formation, volume $\backslash$ euros & 1 & 1 & 3 \\
\hline 290 & Spain & Labor force $\backslash$ persons & 1 & 1 & 3 \\
\hline 291 & Spain & Imports of goods and services, volume, national accounts basis $\backslash$ euros & 1 & 1 & 3 \\
\hline 292 & Spain & Factor income paid abroad, volume, balance of payments basis $\backslash$ local currency & 1 & 1 & 3 \\
\hline 293 & Spain & Labor productivity of the total economy $\backslash$ index & 1 & 1 & 3 \\
\hline 294 & Spain & Labor productivity of the business economy $\backslash$ euros & 1 & 1 & 3 \\
\hline 295 & Spain & Government saving (net), value $\backslash$ euros & 1 & $\mathrm{nl}$ & 2 \\
\hline 296 & Spain & Household saving, value $\backslash$ euros & 1 & 1 & 3 \\
\hline 297 & Spain & Current transfers received by households, value $\backslash$ euros & 1 & 1 & 3 \\
\hline 298 & Spain & Unit labor cost of the total economy $\backslash$ index & 1 & 1 & 3 \\
\hline 299 & Spain & Unit labor cost of the manufacturing sector $\backslash$ index & 1 & 1 & 3 \\
\hline 300 & Spain & Unemployment $\backslash$ persons & 1 & 1 & 3 \\
\hline 301 & Spain & Unemployment rate $\backslash$ percent & 1 & $\mathrm{nl}$ & 2 \\
\hline 302 & Spain & Wages, value $\backslash$ euros & 1 & 1 & 3 \\
\hline 303 & Spain & Wage rate of the business sector $\backslash$ euros/man/year & 1 & 1 & 3 \\
\hline 304 & Spain & Compensation rate of government employees $\backslash$ euros & 1 & 1 & 3 \\
\hline 305 & Spain & Compensation rate of the business sector $\backslash$ yearly salary in euros & 1 & 1 & 3 \\
\hline 306 & Spain & Compensation of employees, value $\backslash$ euros & 1 & 1 & 3 \\
\hline 307 & Spain & Exports of goods and services, volume, national accounts basis $\backslash$ euros & 1 & 1 & 3 \\
\hline 308 & Spain & Factor income from abroad, volume, balance of payments basis $\backslash$ local currency & 1 & 1 & 3 \\
\hline 309 & Spain & Household disposable income, real $\backslash$ euros & 1 & 1 & 3 \\
\hline 310 & Spain & Property income received by households, value $\backslash$ euros & 1 & 1 & 3 \\
\hline 311 & Spain & Government current disbursements, value $\backslash$ euros & 1 & 1 & 3 \\
\hline 312 & Spain & Current disbursements of households, value $\backslash$ euros & 1 & l & 3 \\
\hline 313 & Spain & Government current receipts, value $\backslash$ euros & 1 & 1 & 3 \\
\hline 314 & Spain & Current receipts of households, value $\backslash$ euros & 1 & 1 & 3 \\
\hline 315 & Spain & Self-employment income received by households, value $\backslash$ euros & 1 & 1 & 3 \\
\hline 316 & Spain & Other investment liab., N.I.E. & 1 & $\mathrm{nl}$ & 2 \\
\hline 317 & Spain & Exports Prices & 1 & 1 & 3 \\
\hline 318 & Spain & Terms of Trade & 1 & 1 & 3 \\
\hline 319 & Spain & Call money rate (percent per annum, AQM, DEC, average) & 1 & $\mathrm{nl}$ & 2 \\
\hline 320 & Spain & Share prices (index number, AQM, DEC, average) & 1 & 1 & 3 \\
\hline 321 & Spain & PPI / WPI (index number, 2000=100, AQM, DEC, average) & 1 & 1 & 3 \\
\hline 322 & Spain & CPI: (no specifics avail.) (index number, $2000=100, A Q M, D E C$, average) & 1 & 1 & 3 \\
\hline 323 & Spain & Increase in stocks, volume $\backslash$ euros & 0 & $\mathrm{nl}$ & 0 \\
\hline 324 & Spain & Household saving ratio $\backslash$ ratio & 0 & $\mathrm{nl}$ & 0 \\
\hline
\end{tabular}


APPENDIX I. Macroeconomic Series (continued)

\begin{tabular}{|c|c|c|c|c|c|}
\hline Number & Country & Variable Name & Unit Root & $\log$ & Treatment \\
\hline 325 & Spain & Direct investment abroad & 0 & $\mathrm{nl}$ & 0 \\
\hline 326 & Spain & Dir. Invest. in rep. econ., N.I.E. & 0 & $\mathrm{nl}$ & 0 \\
\hline 327 & Spain & Portfolio investment liab., N.I.E. & 0 & $\mathrm{nl}$ & 0 \\
\hline 328 & Spain & Other investment assets & 0 & $\mathrm{nl}$ & 0 \\
\hline 329 & Spain & Financial account, N.I.E. & 0 & $\mathrm{nl}$ & 0 \\
\hline 330 & Spain & Imports Prices & 0 & 1 & 1 \\
\hline 331 & United Kingdom & Balance of income, value, balance of payments basis & 1 & $\mathrm{nl}$ & 2 \\
\hline 332 & United Kingdom & Current account, value & 1 & $\mathrm{nl}$ & 2 \\
\hline 333 & United Kingdom & Government consumption of fixed capital, value $\backslash$ GBP & 1 & 1 & 3 \\
\hline 334 & United Kingdom & Unit capital-labor costs & 1 & 1 & 3 \\
\hline 335 & United Kingdom & Private final consumption expenditure, volume $\backslash 2001 \mathrm{GBP}$ & 1 & 1 & 3 \\
\hline 336 & United Kingdom & Dependent employment $\backslash$ persons & 1 & 1 & 3 \\
\hline 337 & United Kingdom & Dependent employment of the business sector $\backslash$ persons & 1 & 1 & 3 \\
\hline 338 & United Kingdom & Government employment $\backslash$ persons & 1 & l & 3 \\
\hline 339 & United Kingdom & Self-employed $\backslash$ persons & 1 & 1 & 3 \\
\hline 340 & United Kingdom & Total employment $\backslash$ persons & 1 & 1 & 3 \\
\hline 341 & United Kingdom & Employment of the business sector $\backslash$ persons & 1 & 1 & 3 \\
\hline 342 & United Kingdom & Exchange rate, index of US\$ per local currency $\backslash$ index & 1 & 1 & 3 \\
\hline 343 & United Kingdom & Real Effective exchange rate, $2000=100$, ULC-based & 1 & 1 & 3 \\
\hline 344 & United Kingdom & Gross domestic product, volume, market prices $\backslash 2001$ GBP & 1 & 1 & 3 \\
\hline 345 & United Kingdom & Private non-residential fixed capital formation, volume $\backslash \mathrm{GBP}$ & 1 & 1 & 3 \\
\hline 346 & United Kingdom & Fixed investment in construction, volume $\backslash$ GBP 2001 & 1 & 1 & 3 \\
\hline 347 & United Kingdom & Government fixed capital formation, volume $\backslash$ GBP 00 & 1 & 1 & 3 \\
\hline 348 & United Kingdom & Private residential fixed capital formation, volume $\backslash 2001$ GBP & 1 & 1 & 3 \\
\hline 349 & United Kingdom & Fixed investment in machinery and equipment, volume $\backslash$ GBP 2001 & 1 & 1 & 3 \\
\hline 350 & United Kingdom & Private total fixed capital formation, volume $\backslash$ GBP 00 & 1 & 1 & 3 \\
\hline 351 & United Kingdom & Long-term interest rate on government bonds $\backslash$ percent & 1 & $\mathrm{nl}$ & 2 \\
\hline 352 & United Kingdom & Increase in stocks, volume $\backslash 2001 \mathrm{GBP}$ & 1 & $\mathrm{nl}$ & 2 \\
\hline 353 & United Kingdom & Gross total fixed capital formation, volume $\backslash 2001$ GBP & 1 & 1 & 3 \\
\hline 354 & United Kingdom & Capital stock of the business sector, volume \GBP 2001 & 1 & 1 & 3 \\
\hline 355 & United Kingdom & Labor force $\backslash$ persons & 1 & 1 & 3 \\
\hline 356 & United Kingdom & Labor force participation rate & 1 & $\mathrm{nl}$ & 2 \\
\hline 357 & United Kingdom & Imports of goods and services, volume, national accounts basis \GBP 2001 & 1 & 1 & 3 \\
\hline 358 & United Kingdom & Factor income paid abroad, volume, balance of payments basis $\backslash$ GBP & 1 & 1 & 3 \\
\hline 359 & United Kingdom & Labor productivity of the total economy $\backslash$ index 2000 & 1 & 1 & 3 \\
\hline 360 & United Kingdom & Labor productivity of the business economy & 1 & 1 & 3 \\
\hline 361 & United Kingdom & Household saving, value \GBP & 1 & 1 & 3 \\
\hline 362 & United Kingdom & Household saving ratio $\backslash$ percent & 1 & $\mathrm{nl}$ & 2 \\
\hline 363 & United Kingdom & Current transfers received by households, value $\backslash$ GBP & 1 & 1 & 3 \\
\hline 364 & United Kingdom & Unit labor cost of the total economy $\backslash$ index 2000 & 1 & 1 & 3 \\
\hline 365 & United Kingdom & Unit labor cost of the manufacturing sector $\backslash$ index 2001 & 1 & 1 & 3 \\
\hline 366 & United Kingdom & Unemployment $\backslash$ persons & 1 & 1 & 3 \\
\hline 367 & United Kingdom & Wages, value $\backslash \mathrm{GBP}$ & 1 & 1 & 3 \\
\hline 368 & United Kingdom & Wage rate of the business sector $\backslash \mathrm{GBP}$ & 1 & 1 & 3 \\
\hline 369 & United Kingdom & Compensation rate of government employees $\backslash \mathrm{GBP}$ & 1 & 1 & 3 \\
\hline 370 & United Kingdom & Wage rate of the manufacturing sector, hourly earnings $\backslash$ index 2001 & 1 & 1 & 3 \\
\hline 371 & United Kingdom & Compensation rate of the business sector $\backslash$ yearly salary in GBP & 1 & 1 & 3 \\
\hline 372 & United Kingdom & Compensation of employees, value $\backslash \mathrm{GBP}$ & 1 & 1 & 3 \\
\hline 373 & United Kingdom & Exports of goods and services, volume, national accounts basis $\backslash 2001$ GBP & 1 & 1 & 3 \\
\hline 374 & United Kingdom & Factor income from abroad, volume, balance of payments basis $\backslash \mathrm{GBP}$ & 1 & 1 & 3 \\
\hline 375 & United Kingdom & Household disposable income, real \GBP & 1 & 1 & 3 \\
\hline 376 & United Kingdom & Property income received by households, value & 1 & 1 & 3 \\
\hline 377 & United Kingdom & Government current disbursements, value $\backslash \mathrm{GBP}$ & 1 & 1 & 3 \\
\hline 378 & United Kingdom & Current disbursements of households, value $\backslash$ GBP & 1 & 1 & 3 \\
\hline 379 & United Kingdom & Government current receipts, value $\backslash$ GBP & 1 & 1 & 3 \\
\hline 380 & United Kingdom & Current receipts of households, value $\backslash \mathrm{GBP}$ & 1 & 1 & 3 \\
\hline 381 & United Kingdom & Self-employment income received by households, value $\backslash$ GBP & 1 & 1 & 3 \\
\hline 382 & United Kingdom & Exports prices & 1 & 1 & 3 \\
\hline 383 & United Kingdom & Imports prices & 1 & 1 & 3 \\
\hline 384 & United Kingdom & Terms of trade & 1 & 1 & 3 \\
\hline 385 & United Kingdom & Overnight interbank min (percent per annum, AQM, DEC, average) & 1 & $\mathrm{nl}$ & 2 \\
\hline 386 & United Kingdom & United Kingdom - PPI / WPI (index number, $2000=100$, AQM, DEC, average) & 1 & 1 & 3 \\
\hline 387 & United Kingdom & United Kingdom - CPI: all items (index number, 2000=100, AQM, DEC, average) & 1 & 1 & 3 \\
\hline 388 & United Kingdom & FTSE 100 & 1 & 1 & 3 \\
\hline 389 & United Kingdom & Other investment assets & 1 & $\mathrm{nl}$ & 2 \\
\hline 390 & United Kingdom & Other investment liab., N.I.E. & 1 & $\mathrm{nl}$ & 2 \\
\hline 391 & United Kingdom & United Kingdom\cyclical indicators/surveys of manufacturing industry:|current level & 1 & 1 & 3 \\
\hline 392 & United Kingdom & Cyclical indicatorslsurveys of manufacturing industry:|composite industrial & 0 & $\mathrm{nl}$ & 0 \\
\hline 393 & United Kingdom & Cyclical indicatorslconsumer opinion on economic and financial & 0 & $\mathrm{nl}$ & 0 \\
\hline 394 & United Kingdom & Government saving (net), value $\backslash$ GBP & 0 & $\mathrm{nl}$ & 0 \\
\hline 395 & United Kingdom & Unemployment rate $\backslash$ percent & 0 & $\mathrm{nl}$ & 0 \\
\hline 396 & United Kingdom & Direct investment abroad & 0 & $\mathrm{nl}$ & 0 \\
\hline 397 & United Kingdom & Dir. invest. in Rep. Econ.., N.I.E. & 0 & $\mathrm{nl}$ & 0 \\
\hline 398 & United Kingdom & Portfolio investment assets & 0 & $\mathrm{nl}$ & 0 \\
\hline 399 & United Kingdom & Portfolio investment liab., N.I.E. & 0 & $\mathrm{nl}$ & 0 \\
\hline 400 & United Kingdom & Financial account, N.I.E. & 0 & $\mathrm{nl}$ & 0 \\
\hline 401 & United States & Balance of income, value, balance of payments basis $\backslash$ U.S. dollar & 1 & $\mathrm{nl}$ & 2 \\
\hline 402 & United States & Current account, value in US\$ \U.S. dollar & 1 & $\mathrm{nl}$ & 2 \\
\hline 403 & United States & Government consumption of fixed capital, value $\backslash$ U.S. dollar & 1 & 1 & 3 \\
\hline 404 & United States & Private final consumption expenditure, volume $\backslash$ U.S. dollar & 1 & 1 & 3 \\
\hline 405 & United States & Employment, country specific, variable a \U.S. dollar & 1 & 1 & 3 \\
\hline
\end{tabular}


APPENDIX I. Macroeconomic Series (concluded)

\begin{tabular}{|c|c|c|c|c|c|}
\hline \multicolumn{2}{|c|}{ Number Country } & \multirow{2}{*}{$\begin{array}{l}\text { Variable Name } \\
\text { Dependent employment } \backslash \text { U.S. dollar }\end{array}$} & \multirow{2}{*}{$\begin{array}{r}\text { Unit Root } \\
1\end{array}$} & \multirow{2}{*}{$\frac{\log }{1}$} & \multirow{2}{*}{$\frac{\text { Treatmen }}{3}$} \\
\hline 406 & United States & & & & \\
\hline 407 & United States & Dependent employment of the business sector $\backslash$ U.S. dollar & 1 & 1 & 3 \\
\hline 408 & United States & Government employment $\backslash$ U.S. dollar & 1 & 1 & 3 \\
\hline 409 & United States & Self-employed $\backslash$ U.S. dollar & 1 & 1 & 3 \\
\hline 410 & United States & Total employment $\backslash$ U.S. dollar & 1 & 1 & 3 \\
\hline 411 & United States & Employment of the business sector $\backslash$ U.S. dollar & 1 & l & 3 \\
\hline 412 & United States & Real Effective exchange rate, $2000=100$, ULC-based & 1 & 1 & 3 \\
\hline 413 & United States & Gross domestic product, volume, market prices $\backslash$ U.S. dollar & 1 & 1 & 3 \\
\hline 414 & United States & Private nonresidential fixed capital formation, volume $\backslash$ U.S. dollar & 1 & 1 & 3 \\
\hline 415 & United States & Government fixed capital formation, volume $\backslash$ U.S. dollar & 1 & 1 & 3 \\
\hline 416 & United States & Industrial production $\backslash$ U.S. dollar & 1 & 1 & 3 \\
\hline 417 & United States & Private total fixed capital formation, volume $\backslash$ U.S. dollar & 1 & 1 & 3 \\
\hline 418 & United States & Long-term interest rate on government bonds $\backslash$ U.S. dollar & 1 & $\mathrm{nl}$ & 2 \\
\hline 419 & United States & Long-term interest rate on corporate bonds $\backslash$ U.S. dollar & 1 & $\mathrm{nl}$ & 2 \\
\hline 420 & United States & Short-term interest rate $\backslash$ U.S. dollar & 1 & $\mathrm{nl}$ & 2 \\
\hline 421 & United States & Gross total fixed capital formation, volume $\backslash$ U.S. dollar & 1 & 1 & 3 \\
\hline 422 & United States & Capital stock of the business sector, volume $\backslash$ U.S. dollar & 1 & 1 & 3 \\
\hline 423 & United States & Capital stock, housing, volume $\backslash$ U.S. dollar & 1 & 1 & 3 \\
\hline 424 & United States & Labor force $\backslash$ U.S. dollar & 1 & 1 & 3 \\
\hline 425 & United States & Labor force participation rate $\backslash$ U.S. dollar & 1 & $\mathrm{nl}$ & 2 \\
\hline 426 & United States & Imports of goods and services, volume, national accounts basis $\backslash$ U.S. dollar & 1 & 1 & 3 \\
\hline 427 & United States & Money supply, narrow definition: base money, M1 or M2 \U.S. dollar & 1 & 1 & 3 \\
\hline 428 & United States & Money supply, broad definition: M2 or M3 \U.S. dollar & 1 & l & 3 \\
\hline 429 & United States & Factor income paid abroad, volume, balance of payments basis $\backslash$ U.S. dollar & 1 & 1 & 3 \\
\hline 430 & United States & Labor productivity of the total economy $\backslash$ U.S. dollar & 1 & 1 & 3 \\
\hline 431 & United States & Labor productivity of the business economy $\backslash$ U.S. dollar & 1 & 1 & 3 \\
\hline 432 & United States & Household saving ratio $\backslash$ U.S. dollar & 1 & $\mathrm{nl}$ & 2 \\
\hline 433 & United States & Current transfers received by households, value $\backslash$ U.S. dollar & 1 & 1 & 3 \\
\hline 434 & United States & Unit labor cost of the total economy $\backslash$ U.S. dollar & 1 & 1 & 3 \\
\hline 435 & United States & Unit labor costs in the business sector $\backslash$ U.S. dollar & 1 & 1 & 3 \\
\hline 436 & United States & Unit labor cost of the manufacturing sector $\backslash$ U.S. dollar & 1 & 1 & 3 \\
\hline 437 & United States & Velocity of money $\backslash$ U.S. dollar & 1 & 1 & 3 \\
\hline 438 & United States & Wages, value $\backslash$ U.S. dollar & 1 & 1 & 3 \\
\hline 439 & United States & Wages of the government sector, value $\backslash$ U.S. dollar & 1 & 1 & 3 \\
\hline 440 & United States & Wage rate of the business sector $\backslash$ U.S. dollar & 1 & 1 & 3 \\
\hline 441 & United States & Compensation rate of government employees $\backslash$ U.S. dollar & 1 & 1 & 3 \\
\hline 442 & United States & Wage rate of the manufacturing sector, hourly earnings $\backslash$ U.S. dollar & 1 & l & 3 \\
\hline 443 & United States & Compensation rate of the business sector $\backslash$ U.S. dollar & 1 & 1 & 3 \\
\hline 444 & United States & Compensation of employees, value \U.S. dollar & 1 & 1 & 3 \\
\hline 445 & United States & Exports of goods and services, volume, national accounts basis $\backslash$ U.S. dollar & 1 & 1 & 3 \\
\hline 446 & United States & Factor income from abroad, volume, balance of payments basis $\backslash$ U.S. dollar & 1 & 1 & 3 \\
\hline 447 & United States & Household disposable income, real $\backslash$ U.S. dollar & 1 & 1 & 3 \\
\hline 448 & United States & Property income received by households, value $\backslash$ U.S. dollar & 1 & 1 & 3 \\
\hline 449 & United States & Government current disbursements, value $\backslash$ U.S. dollar & 1 & 1 & 3 \\
\hline 450 & United States & Current disbursements of households, value $\backslash$ U.S. dollar & 1 & 1 & 3 \\
\hline 451 & United States & Government current receipts, value $\backslash$ U.S. dollar & 1 & 1 & 3 \\
\hline 452 & United States & Current receipts of households, value $\backslash$ U.S. dollar & 1 & 1 & 3 \\
\hline 453 & United States & Self-employment income received by households, value $\backslash$ U.S. dollar & 1 & 1 & 3 \\
\hline 454 & United States & Direct investment abroad & 1 & $\mathrm{nl}$ & 2 \\
\hline 455 & United States & Dir. invest. in rep. econ., N.I.E. & 1 & $\mathrm{nl}$ & 2 \\
\hline 456 & United States & Portfolio investment assets & 1 & $\mathrm{nl}$ & 2 \\
\hline 457 & United States & Portfolio investment liab., N.I.E. & 1 & $\mathrm{nl}$ & 2 \\
\hline 458 & United States & Financial account, N.I.E. & 1 & $\mathrm{nl}$ & 2 \\
\hline 459 & United States & Exports prices & 1 & 1 & 3 \\
\hline 460 & United States & Imports prices & 1 & 1 & 3 \\
\hline 461 & United States & Terms of trade & 1 & 1 & 3 \\
\hline 462 & United States & PPI / WPI (index number, 2000=100, AQM, DEC, average) & 1 & 1 & 3 \\
\hline 463 & United States & CPI all items city average (index number, $2000=100, \mathrm{AQM}, \mathrm{DEC}$, average) & 1 & 1 & 3 \\
\hline 464 & United States & Share prices: industrial (index number, AQM, DEC, average) & 1 & 1 & 3 \\
\hline 465 & United States & Cyclical indicatorslbusiness climate: consumers confidencel1985 = $100 \mathrm{SA}$ & 0 & $\mathrm{nl}$ & 0 \\
\hline 466 & United States & USA PMI business confidence & 0 & $\mathrm{nl}$ & 0 \\
\hline 467 & United States & Fixed investment in nonresidential construction, volume $\backslash$ U.S. dollar & 0 & 1 & 1 \\
\hline 468 & United States & Private residential fixed capital formation, volume $\backslash$ U.S. dollar & 0 & 1 & 1 \\
\hline 469 & United States & Fixed investment in machinery and equipment, volume $\backslash$ U.S. dollar & 0 & 1 & 1 \\
\hline 470 & United States & Increase in stocks, volume $\backslash$ U.S. dollar & 0 & $\mathrm{nl}$ & 0 \\
\hline 471 & United States & Government saving(net), value $\backslash$ U.S. dollar & 0 & $\mathrm{nl}$ & 0 \\
\hline 472 & United States & Household saving, value $\backslash$ U.S. dollar & 0 & 1 & 1 \\
\hline 473 & United States & Unemployment $\backslash$ U.S. dollar & 0 & 1 & 1 \\
\hline 474 & United States & Unemployment rate $\backslash$ U.S. dollar & 0 & $\mathrm{nl}$ & 0 \\
\hline 475 & United States & Production/rate of capacity utilisat & 0 & $\mathrm{nl}$ & 0 \\
\hline 476 & United States & Other investment assets & 0 & $\mathrm{nl}$ & 0 \\
\hline 477 & United States & Other investment liab., N.I.E. & 0 & $\mathrm{nl}$ & 0 \\
\hline 478 & World & Commodity Food and Beverage Price Index, $1995=100$, includes Food and & 1 & 1 & 3 \\
\hline 479 & World & Crude Oil (petroleum), simple average of three spot prices; Dated Brent, West Texas & 1 & 1 & 3 \\
\hline 480 & World & Commodity Metals Price Index, $1995=100$, includes Copper, Aluminum, Iron Ore, & 1 & 1 & 3 \\
\hline 481 & World & Commodity Nonfuel Price Index, $1995=100$, includes Food and Beverages and & 1 & 1 & 3 \\
\hline 482 & World & Commodity Industrial Inputs Price Index, $1995=100$, includes Agricultural Raw & 0 & 1 & 1 \\
\hline 483 & G7 excl. France & Gross domestic product, volume, index number & 1 & 1 & 3 \\
\hline 484 & G7 excl. France & Consumer Price Index (SA, 2000=100), index number & 1 & 1 & 3 \\
\hline 485 & Euro area excl. France & Gross domestic product, volume, euro & 1 & 1 & 3 \\
\hline 486 & Euro area excl. France & Gross domestic product deflator, index number & 1 & 1 & 3 \\
\hline
\end{tabular}

Nota bene: Integrated of order $0=0,1=1,2=2$; not integrated of order 1 or $2=$ NS; natural $\log$ variables $=1$; no transformation $=$ nl.

0 : no transformation; 1: logarithm; 2: first difference; 3: first difference of logarithm. 


\section{References}

Altig, D., L.J. Christiano, M. Eichenbaum, and J. Linde, 2002, “Technology Shocks and Aggregate Fluctuations,” manuscript.

Anderton, R., F. di Mauro, and F. Moneta, 2004, “Understanding the Impact of the External Dimension of the Euro Area: Trade, Capital Flows and Other International Macroeconomic Linkages,” ECB, ECB Occasional Paper 12.

Bai, J., and S. Ng, 2002, "Determining the Number of Factors in Approximate Factor Models," Econometrica, 70(1), pp. 191-221.

Canova, F., and G. de Nicoló, 2003, “On the Sources of Business Cycles in the G-7,” Journal of International Economics, 46, pp. 133-66.

Chamberlain, G., 1983, "Funds, Factors, and Diversification in Arbitrage Pricing Models,” Econometrica 51, pp. 1281-304.

Chamberlain, G., and M. Rothschild, 1983, “Arbitrage, Factor Structure and Mean-Variance Analysis in Large Markets,” Econometrica 51, pp. 1305-24.

Eickmeier, S., "Business Cycle Transmission from the U.S. to Germany-A Structural Factor Approach,” European Economic Review, forthcoming.

Eickmeier, S., and J. Breitung, 2006, "How Synchronized are Central East European Economies with the Euro Area? Evidence from a Structural Factor Model,” Journal of Comparative Economics, 34(3), pp. 538-563.

Eickmeier, S., 2006, “Comovements and Heterogeneity in the Euro Area Analyzed in a Nonstationary Dynamic Factor Model”, Bundesbank, Discussion Paper, Series 1, 31/2006.

Elliott, G., T.J. Rothenberg, and J. Stock, 1996, “Efficient Tests for an Autoregressive Unit Root,” Econometrica 64, pp. 813-36.

Fernández-Villaverde, J., J. Rubio-Ramírez, T. J. Sargent, and M.W. Watson, 2005, “A, B, C’s (and D)’s for Understanding VARs,” NBER Technical Working Papers No. 0308.

Forni, M., M. Hallin, F. Lippi, and L. Reichlin, 2000, “The Generalized Dynamic Factor Model: Identification and Estimation,” The Review of Economics and Statistics 82(4), pp. 540-54.

Forni, M., D. Giannone, M. Lippi, and L. Reichlin, 2005, “Opening the Black Box: Structural Factor Models with Large Cross-Sections,” manuscript.

Geweke, J., 1977, “The Dynamic Factor Analysis of Economic Time Series,” in Latent Variables in Socio-Economic Models; edited by D.J. Aigner and A.S. Golberger (Amsterdam: North-Holland), p. 19. 
Giannone, D., L. Reichlin, and L. Sala, 2002, “Tracking Greenspan: Systematic and Unsystematic Monetary Policy Revised,” CEPR Working Paper 3550.

Hansen, L.P. and T.J. Sargent, 1991, “Two Problems in interpreting Vector Autoregressions,” in L.P. Hansen and T.J. Sargent, eds., Rational Expectations Econometrics, Boulder: Westview, pp. 77-119.

Kabundi, A., 2004, "Estimation of Economic Growth Using Business Survey Data,” International Monetary Fund, WP/04/69.

Kapetanios, G. and M. Marcellino, 2006, “A Parametric Estimation Method for Dynamic Factor Models of Large Dimensions”, CEPR Discussion Paper No. 5620, April.

King, R.G., C.I. Plosser, J.H. Stock and M.W. Watson, 1991, "Stochastic Trends and Economic Fluctuations,” American Economic Review, 83, pp. 819-40.

Kose, M.A., and K. Yi, 2001, "International Trade and Business Cycles: Is Vertical Integration the Missing Link?” American Economic Association Papers and Proceedings, 91(2), pp. 371-5.

Kose, M.A., E.S. Prasad, and M.E. Terrones, 2003, "How Does Globalization Affect the Synchronization of Business Cycles?” American Economic Association Papers and Proceedings, 93(2), pp. 57-62.

Kose, M.A., C. Otrok, and C.H. Whiteman, 2003, "International Business Cycles: World, Region, and Country-Specific Factors,” American Economic Review, 93(4), pp. 1216-39.

Kwiatowski, D., P.C.B. Phillips, P. Schmidt, and Y. Shin, 1992, "Testing the Null Hypothesis of Stationarity Against the Alternative of a Unit Root: How Sure Are We That Economic Time Series Have a Unit Root?” Journal of Econometrics, 54, pp.159-78.

Imbs, J., 2004, “Trade, Finance, Specialization and Synchronization,” Review of Economics and Statistics, 86(3), pp. 723-34.

IMF, 2001, “World Economic Outlook,” International Monetary Fund, October, pp. 65-79.

IMF, 2004, “GEM: A New International Macroeconomic Model,” International Monetary Fund.

Lumsdaine, R.L. and E.S. Prasad, 2003, "Identifying the Common Component in International Economic Fluctuations: A New Approach,” The Economic Journal, 113(484), pp. 101-27.

Montfort, A., J.P. Rennee, R. Rüffer, and G. Vitale, 2004, "Is Economic Activity in the G7 Synchronized? Common Shocks Versus Spillover Effects,” Journal of International Economics, 40, pp. 85-104. 
Nadal De Simone, F., 2003, “Common and Idiosyncratic Components in Real Output: Further International Evidence,” International Monetary Fund WP/02/229.

Nadal De Simone, F., 2005, “Recent French Inflation Behavior: Is It any Different from the Euro Area's?” International Monetary Fund, IMF Country Report 05/397.

Nadal De Simone, F., 2007, “Asymmetry in Business Fluctuations: International Evidence on Friedman’s Plucking Model,” Journal of International Money and Finance, 26(1), pp. 6485.

Peersman, G., 2003, "What Caused the Early Millennium Slowdown? Evidence Based on Vector Autoregressions,” Journal of Applied Econometrics, 20, pp. 185-207.

Sargent, T.J., and C.A. Sims, 1977, "Business Cycle Modeling without Pretending to have too Much a Priori Economic Theory," in New Methods in Business Research, edited by C.A. Sims (Minneapolis: Federal Reserve Bank of Minneapolis).

Sims, C. A., 1992, "Interpreting the Macroeconomic Time Series Facts. The Effects of Monetary Policy”, European Economic Review, 36, pp. 975-1011.

Sims, C.A. and T. Zha, 1999, “Error Bands for Impulse Responses,” Econometrica 67(5), pp. 1113-55.

Stock, J.H., and M.H. Watson, 1998, “Diffusion Indexes,” NBER Working Paper 6702.

Stock, J.H., and M.H. Watson, 2002, "Macroeconomic Forecasting Using Diffusion Indexes,” Journal of Business \& Economic Statistics, 20(2), pp. 147-162.

Uhlig, H., 2003, “What Moves Real GNP?” manuscript. 